\title{
ARCHAEOLOGY
}

\section{SARMATIAN NECROPOLIS FROM MEDELENI (COM. PETREŞTI, UNGHENI DISTRICT, REPUBLIC OF MOLDOVA)}

\begin{abstract}
Medeleni sarmatian cemetery is located at the left side of the road Chișinău-Sculeni, about $1 \mathrm{~km}$ north of the river Prut and 1,3 km northnorth-east of the Medeleni village. Reported in the winter of 2015 during the reconstruction of the irrigation system in Blindesti, the site was partially investigated, by rescue excavation, this spring. It was explored an area of 864 square meters, there havingbeen discovered five north-south oriented inhumation graves and a religiouscomplex bounded by grooves and provided with entrance in the south. All thegraves were disturbed in antiquity, skeletons being partially or fully torn. According to the inventory and anthropological measurements, the graves belonged to females people. From all complexes, stands the tomb 1 , which wasprovided with a rich inventory, consisting of three pendants and 11 vestment goldapplies, 13 agate beads and a clay spindle whorl. The analysis of the inventory items with chronological value and of other objects confirm the dating ofdiscovered complexes in the second half of the century I - century II AD. Regarding the ethnic-cultural affiliation, rite, funerary practices and inventory items plead for assigning Medeleni necropolis to Sarmatian antiquities.
\end{abstract}

Keywords: Middle Prut Plain, plane necropolis, tomb, the Roman period, Sarmatians.

\section{INTRODUCTION}

eographically, Medeleni village (Com. Petreşti, Ungheni District) (Fig. $1 / 1)$ is placed in the central part of the Middle Prut Plain, a region extremely rich in archaeological sites, dating from the Palaeolithic and until the modern era. The large number of archaeological sites, consisting of settlements, plane cemeteries and burial mounds, discovered during surface or rescue research in the Petreşti micro zone to which the Medeleni locality belongs, shows over time the interest of human communities for the complex of natural factors, that had contributed to the creation of favourable conditions for human habitation.

Among archaeological monuments from the Petreşti micro zone, the Roman plane necropolis particularly stands out with two culturalchronological horizons, one being assigned to Sarmatians from II-III century $\mathrm{AD}$ and another belonging to Sântana de Mureș-Chernyakhov culture from the Goths migration time (the second half of III century - IV century AD). Being locate $\mathrm{d}$ on a promontory south-west of the locality, at a distance of about $0.1 \mathrm{~km}$ from the Chișinau-Sculeni road junction with the road leading to Petreşti (Fig. 2/1), this ancient necropolis was discovered in 1986 during

\section{Vlad Vornic}

National Archaeological Agency, Chișinău vornic.vlad@yahoo.com

\section{Valeriu Bubulici}

The National Museum of History of Moldova, Chișinau

vbubulici@mail.ru

\section{Sergiu Popovici}

National Archaeological Agency, Chișinău sergiupopovici1986@gmail.com 
rescue excavations at a prehistoric mound, entering into the construction area of the irrigation system near Petreşti village. In 1986 and 1988 the entire surface of the site was unveiled by wide-sprea $d$ ing research, being disclosed 46 tombs, 35 Sarmatian cult ditches and 195 Sântana de Mureș type funerals, of which 190 burial and 5 cremation. In addition, a rich funeral inventory was collected, consisting of pottery and glass vessels, pieces of jewellery and clothing, tools and utensils made of metal, stone, clay and other materials ${ }^{1}$.

Another extremely valuable archaeological site is the Sarmatian cemetery recently discovered in Medeleni, located on the left side of the Chișinău-Sculeni road, about $1 \mathrm{~km}$ west of the ancient necropolis of Petreşti, about $1 \mathrm{~km}$ north of the Prut river and 1,3 km northeast of the Medeleni locality (Fig. 1/2; 2/2). Mentioned in the winter of 2015, at the reconstruction of the Blindesti irrigation system, when a burial tomb provided with rich inventory, including a few pieces of gold ${ }^{2}$, was discovered and partially destroyed, the necropolis we refer was partially investigated by rescue excavations effectuated this spring by the National Archaeological Agency in cooperation with the National Museum of History of Moldova from Chișinău and the Museum of History and Ethnography from Ungheni ${ }^{3}$.

In terms of topography, the funeral site at Medeleni is located on a relatively flat promontory, particularly in its eastern part. Using satellite images and surface research data eight mounds of various sizes have been identified on its surface (Fig. 2/2). Until recently, only one of them was known to specialists, larger in dimensions, it was marked on some older topographic maps and included into the archaeological repertoire of the Ungheni district developed in $1993^{4}$. During research on the plateau surface, there were recovered several pieces of flint, confirming the existence here or in the immediate vicinity of a resort dating from the Upper Palaeolithic (XXX-X mil. BC), a few small shards of hand-made vessels or amphorae dating from prehistory, antiquity or the Middle Ages, a bronze bell belonging to

KURCHATOV 1989，74-75; KURCEATOV/BUBULICI 2001，33-37; KURCEATOV/VORNIC 2005, 87-95.

2 The discovery was made by workers in the morning of February 9, when digging the ditch for installing new pipes in the irrigation system a human skull appeared, which was broken, and around it an object of adornment was found in form of amphorette, worked of yellow metal. Not realizing that they were facing a major archaeological discovery, but believing they see the skeleton of a recently buried person, the workers stopped working immediately and announced the Ungheni Police Inspectorate. Arriving soon at the place, Mr. Vadim Popovich, Lieutenant-Colonel of Police, the Chief of Police District no. 2 (Sculeni) of the Ungheni Police Inspectorate, together with two other policemen and workers from the irrigation system, using an excavator, during the day of 9 February, "dug" entirely the tomb, where human bones and many ornaments and port goods of gold, agate beads, a burned clay spindle whorl and a piece of flint were collected. Archaeological National Agency received the information about this discovery on 12 February, it being provided by Mr. Vasile Iucal, the director of the Ungheni Museum of History and Ethnography, who showed us some photos of the discovered objects. In the following days (February 13 to 14) the National Archaeological Agency collaborators carried out a visit to Ungheni and Medeleni to recover from the Police Inspectorate the archaeological goods and for inspection and prospecting of the place with the archaeological discovery.

Investigations were financed by SRL SADE-Compagnie General Travaux d'Hidraulique. At the archaeological field investigations archaeologist and Ion Noroc and also the historian Vasile lucal, the director of the Ungheni Museum of History and Ethnography, participated as well.

4 COVALENCO 1993, 24; COVALENCO 2006, 27.
Sarmatian necropolis from I-II century AD, and several iron pieces of the late Middle Ages (XVI-XVII century) (Fig. 3).

\section{DESCRIPTION OF EXCAVATIONS AND COMPLEXES}

Archaeological rescue excavations have focused on the southern part of the irrigation ditch, oriented on west-east general direction. Initially, a box was traced with dimensions of $2 \times 3 \mathrm{~m}$ and north-south orientation in the place, where workers found a grave. Later, there was traced a large section of rectangular shape with dimensions of 18 $\times 48 \mathrm{~m}$ and orientation of the long sides west-east, which included also the tomb 1 box (Fig. 4).

The vertical stratigraphy of the excavation is as follows: ploughed gray colour soil, 0,4-0,5 m thick; yellowishbrown transition soil, 0,3-0,4 m thick; living clay at a depth of 0,9-1,1 $\mathrm{m}$ from the current ground level.

Five burial tombs and a ditch of worship have been identified and examined in the excavation perimeter, at a depth of $0.9-1.1 \mathrm{~m}$, on the living soil background, all complexes belonging to a plane Sarmatian cemetery dating from I-II century AD.

Grave 1 (Fig. 4-6) was reported by workers in the southern wall of the irrigation trench, the skeleton being uncovered in the absence of archaeologists by workers and several policemen from the Ungheni Police Inspectorate headed by Vadim Popovich. To relieve the earth above the skeleton an excavator was used as well, blade traces of which were captured clearly in the box, traced later by the archaeologists. The box with dimensions of $3 \times 4 \mathrm{~m}$ and side orientation toward the cardinal points was executed for methodical research of the tomb and recording of all the relevant archaeological data. It has been noted however that, unfortunately, the grave was almost totally destroyed, only the southern end of the burial pit on a length of $0,2 \mathrm{~m}$ and a depth of about $10 \mathrm{~cm}$ being kept. It was established that the general orientation of the pit was north-south, roughly rectangular shape in plan, about $1.0 \mathrm{~m}$ wide, with relatively vertical walls, bottom straight and about $1,35 \mathrm{~m}$ depth from the current surface of the ground, but $0,25 \mathrm{~m}$ from the identification level. The length of the tomb pit could not be determined, because its northern end was destroyed by the irrigation system trench. Filling of the pit consisted of gray earth, without other materials than those collected by the policemen and workers.

According to the information offered by Vadim Popovici, the skeleton was laid back in prone position, with hands placed along the body, having a north-south general orientation. It seems that the grave was disturbed in antiquity, some bones of the chest were found in the region of legs. According to anthropological determinations, the skeleton (whose bones were mostly the contents of the grave, all gathered by the policemen) belonged to a woman of advanced age at death, more than 60 years (senilis). As an anthropological type, this female skeleton represents a mixture of easteuropoid characters with Mediterranean elements.

The grave contained a rich inventory, being recovered a total of 29 objects, intact or fragmentary, like a gold earring or pendant, a pendant worked of gold and rock crystal, 
a tubular pendant of gold and glass, 11 gold appliqués of different forms, 13 agate beads, a clay spindle and a piece of flint.

Below is a detailed description of all these goods:

1. Pendant (Fig. 7/3) in form of an amphorette provided with a suspension ring and 13 chains (two of which are missing from antiquity); piece length: $5,3 \mathrm{~cm}$. The amphorette has a bitronconic body, conical neck, widen out edge, round mouth, covered with a gold sheet, splayed leg, finished in a prismatic pedestal with a square base; amphorette height together with the suspension hook: $3,2 \mathrm{~cm}$, maximum diameter of the amphorette: $1,45 \mathrm{~cm}$; height from the base to the maximum diameter: $1,55 \mathrm{~cm}$; height from the maximum diameter to the top: $1,65 \mathrm{~cm}$; amphorette mouth diameter: 0,65 $\mathrm{mm}$; amphorette base dimensions: $1 \times 1 \mathrm{~cm}$; pedestal height: $0,25 \mathrm{~cm}$. The grip ring is worked of a strip provided with two ditched decorations on the top; link height: $0.4 \mathrm{~cm}$, link width: $0,7 \mathrm{~cm}$; strip width: $0,25 \mathrm{~cm}$; strip thickness: $0,1 \mathrm{~cm}$. The amphorette is provided with four handles made of a strip with ditched decoration on the outer surface, welded to the mouth edge close to the maximum diameter, two along the suspension ring, and the other two in cross; handles length: $1,2 \mathrm{~cm}$; width: $0,13 \mathrm{~cm}$. The amphorette body is decorated on the shoulder and at the bottom by one band each, consisting of small pellets, about $0,05 \mathrm{~cm}$ in diameter, and between bands and the maximum diameter, by four cells in the form of hearts, their apex directed toward the maximum diameter, filled with yellowish glassy paste. Cells have dimensions 0,4 $\times 0,4 \mathrm{~cm}$ and are made of thin gold wire with a diameter of $0,05 \mathrm{~cm}$. Between cells two links of thin wire (eight overall) are located, to which a chain was attached; links diameter: $0,3 \mathrm{~cm}$; two chains are missing and one - broken, being kept only for a length of $1,3 \mathrm{~cm}$. The chains are made of thin wire entwisted in four; chains length: $4,2 \mathrm{~cm}$; wire thickness: $0,05 \mathrm{~cm}$. At the ends each have a pendant of wire with links attached to the chain and twisted four times under the link, on which a spheroid white bead of glass paste is attached (only three items were preserved), and a hemisphericalshaped piece of gold sheet, perforated in the centre, below which one tiny blue glass beads are located; beads diameter: $0,2 \mathrm{~cm}$; hemispherical piece diameter: $0,4 \mathrm{~cm}$. Below the amphorette base the other five links of thin wire with a diameter of 16 to $2 \mathrm{~mm}$ are located, four arranged at the corners and one in the centre, to which five identical with other chains are attached, provided with glass beads made of white glassy paste (one missing), and gold hemispherical pieces with blue glass beads at the ends, but with the length of $1,8 \mathrm{~cm}$. On the upper part of the amphorette leg, at the four corners, a pyramid composed of four granules, three at bottom and one above, is presented as decoration.

The piece was found near the skeleton skull.

2. Prism-shaped gold pendant (Fig. 7/1) with hexagonal base and a suspension ring with an embedded prismatic piece with hexagonal base made of colourless rock crystal; inner and outer edges of the mount, each having a little revealed band, decorated in au repouse technique reproducing two plaited fibbers; pendant length: $2,4 \mathrm{~cm}$; mount length without ring: $2,3 \mathrm{~cm}$; mount diameter: $0.5 \mathrm{~m}$; prismatic piece thickness: $2,3 \mathrm{~cm}$; grip ring length $0,4 \mathrm{~cm}$.
3. Tubular pendant (Fig. 7/2) of green glass, having the ends sealed with a gold mount, each provided with a suspension ring of gold strip with longitudinal grooving on the outer side; inner and outer edges of mounts, each having a belt in relief, decorated in the au repouse technique reproducing three plaited fibbers; inside the tube is a white substance, indeterminate (chalk?); pendants length: $4,4 \mathrm{~cm}$; tube length: $4,3 \mathrm{~cm}$; tube diameter: $0,7 \mathrm{~cm}$; mounts length: $0,5 \mathrm{~cm}$; mounts diameter: $0,9 \mathrm{~cm}$; suspension rings diameter: $0,3 \mathrm{~cm}$; rings width: $0,2 \mathrm{~cm}$.

Pieces from no. 2 and 3 were found near the thorax.

4-10. Seven triangular-shaped gold brackets (Fig. 7/8-14) executed of gold sheet by punching, each provided with a hole at ends for gripping; dimensions: $0.6 \times 0.7 \mathrm{~cm}$.

11-12. An entire appliqué and a fragment from another (Fig. 7/4-5) in the form of rosette with five petals made of gold foil by punching, with bulging centre, the edges of the petals consist of "grains" realized in au repouse technique and holes at the ends of the petals for fastening. Appliqué diameter: $1.15 \mathrm{~cm}$; fragment diameter: $0.4 \times 0.9$ $\mathrm{cm}$.

13-14. Two tubular gold appliqué (Fig. 7/6-7), decorated with transversal ditches, with a length of $0.6 \mathrm{~cm}$ and a diameter of $0,2 \mathrm{~cm}$.

Pieces from no. 4-14 were found in different zones, along the body

15-27. 13 agate barrel-shaped beads (Fig. 7/3), with length ranging between 0.8 and $2.2 \mathrm{~cm}$, section diameter of $0.5-0.7 \mathrm{~cm}$ and holes diameter from 0,15 to $0,20 \mathrm{~cm}$, found in the upper part of the skeleton.

28. Red-brick clay truncated spindle (Fig. 7/3) with diameter of $4 \mathrm{~cm}$ and height of $3 \mathrm{~cm}$, the place of discovery unknown.

29. Flint blade with sizes of $2 \times 3 \mathrm{~cm}$ found in the soil of the grave.

Grave 2 (Fig. 5; 8) was discovered at a distance of about $7.5 \mathrm{~m}$ south-south-east of the tomb 1 . The grave pit was observed at depth of $1.26 \mathrm{~m}$ and it has the north-northeast - south-south-vest orientation. The form of the funeral pit was roughly rectangular, with dimensions of $0.80 \times 2.31$ $\mathrm{m}$, vertical walls and a depth of $0.45 \mathrm{~m}$ from the identification level and $1.66 \mathrm{~m}$ from the current surface of the ground.

The tomb was disturbed in antiquity, some of the skeleton bones, including the skull calotte, missing. The skeleton was totally scattered, bones being in disarray, on the bottom of the pit. According to the paleoanthropological analysis, the skeleton belonged to a female individual, with an age at death of about 35-40 years (early maturus). In the absence of the skull, the anthropological type cannot be identified precisely. However, the mandible presents certain Dinaric characters.

The grave goods include a ceramic pot, an iron rivet, a bronze bracket and some beads of different types.

1. Ceramic vase (Fig. 9/1; 18/2) hand-made of relatively fine paste, with approximately bitruncated body, little revealed flat bottom, mouth tighter than the base and with the edge flaring on the outside. The container was burned in a reducing atmosphere, but incomplete, getting in the outside a gray colour, sometimes black, and brown in section. Because of the scanty burning, the outer surface of 
the vessel is heavily corroded; vessel height: $11.6 \mathrm{~cm}$, mouth diameter: $4.5 \mathrm{~cm}$, maximum diameter: $8.8 \mathrm{~cm}$, bottom diameter: $5.1 \mathrm{~cm}$. The vessel was found in the northern part of the pit, on the bottom, with mouth up, slightly inclined to north-east.

2. Iron rivet (Fig. 9/2) with traces of rotten wood, found in the tomb filling, length: $1.4 \mathrm{~cm}$.

3. Bronze bracket (Fig. 9/3) of approximately discoid form, with a perforation for gripping; diameter: $0.9-1.0 \mathrm{~cm}$; thickness: $0.05 \mathrm{~cm}$. The piece was found in the filling soil above bones.

4-5. Two cylindrical beads (Fig. 9/4-5) of white limestone (?), found in fragmentary condition; length: 1.3$1.5 \mathrm{~cm}$; diameter: $1.1 \mathrm{~cm}$.

6. Flat amber bean (Fig. 9/6) having a quasi rectangular outline; dimensions: $1.8 \times 0.7 \times 0.5 \mathrm{~cm}$.

7-8. Two prismatic-shaped beads (Fig. 9/7-8) with rectangular base of white glass paste inside and green glass paste on the outside; both pieces are fragmentary; dimensions: $1 \times 1.2 \mathrm{~cm}$.

9-11. Three beads (Fig. 9/9-11) in the form of pill, one integral and two fragmentary, of glassy pink paste; diameter: 0,5-0,8 cm; thickness: 0,25 cm.

12-18. Seven small spheroid beads (Fig. 9, 12-18), five of them integral and two fragmentary, of yellow glassy paste; diameter: 0,3-0,4 cm.

16-37. 22 small globular beads (Fig. 9/16-40), including 20 integral and two fragmentary, of glassy graybrown paste; diameter: $0,3-0,5 \mathrm{~cm}$.

Pieces from no. 4-40 were found in the filling soil of the grave.

Grave 3 (Fig. 5; 10) is at a distance of about $18 \mathrm{~m}$ west-south-west of the tomb 1. Funeral pit was observed at depth of $1.26 \mathrm{~cm}$ and it has the depth of $1,73 \mathrm{~m}$ from the current surface of the ground and $0.47 \mathrm{~m}$ from the identification level. The pit has a north-south direction and was approximately rectangular, with a length of 2,08 $\mathrm{m}$ and width of $0,86 \mathrm{~m}$. On the bottom, especially in the central area of the pit, traces of brown rot were observed, probably coming from a vegetable fibber matting.

The tomb was disturbed in antiquity, some of the skeleton bones, including the skull, disappeared. Most bones were scattered in the central part of the pit, only the tibiae being in anatomic position. The skeleton belonged to a female individual with an age at death about $35-40$ years (early maturus). In the absence of the skull, the anthropological type cannot be determined with precision. The mandible presents some Nordic character.

The grave inventory is quite varied, comprising two pottery, two clay spindles, a bronze bucket-shaped pendant, a bronze appliqué and 53 beads made of different materials.

1. Roman pitcher (Fig. 11/1; 18/2) worked of fine paste without visible ingredients in the texture and oxidant burnt to brick-red, but weak, so the vessel was corroded. The container has a spheroid body, narrow and short neck, slightly thickened and flared lip and a flat bottom, little bold. The handle is worked from a band, oval in section, being caught under the lip and to upper body; height: 9,3 $\mathrm{cm}$; mouth diameter: $3,3 \mathrm{~cm}$; maximum diameter: $7,6 \mathrm{~cm}$; bottom diameter: $4 \mathrm{~cm}$. The container was found at the right of the tibiae, the mouth tilted towards north.

2. Clay cup (Fig. 11/2; 18/3) hand-made of relatively fine paste, with small organic ingredients in composition. The colour of the vase is light-brown, in patches with gray spots, due to the uneven burning. The container has an ovalshaped body, with a maximum diameter about mid-height, flared edge and flat bottom, slightly convex. The handle of the vessel is approximately rectangular in section, with the upper end caught to the shoulder and the lower one to the zone of maximum diameter; height: $18,4 \mathrm{~cm}$; mouth diameter: $10 \mathrm{~cm}$; maximum diameter: $12,8 \mathrm{~cm}$; bottom diameter: $7,5 \mathrm{~cm}$. The vessel was found in the region of the legs, at the right of the pins, with the mouth upwards, slightly inclined to the south.

3. Clay gray-brown truncated spindle whorl (Fig. 12/1); diameter: $3.6 \mathrm{~cm}$; height: $1,7 \mathrm{~cm}$; hole diameter: 0,7 $\mathrm{cm}$. The piece was found at the right of the tibiae, among pottery.

4. Clay duck-gray truncated spindle whorl (Fig. 12/2), decorated with incised oblique lines; diameter: $4.6 \mathrm{~cm}$; height: $2.4 \mathrm{~cm}$; hole diameter: $0.7 \mathrm{~cm}$. The spindle was found at the right of the tibiae, together with the piece from no. 6 .

5. Ring (Fig. 12/3) with ends close made of bronze wire, circular in section; ring diameter: $2,5 \mathrm{~cm}$; wire diameter: $0,25 \mathrm{~cm}$. The piece was found in the central area of the tomb, at the right of the human bones.

6. Bucket-shaped bronze cylindrical pendant (Fig. 12/4) found in a fragmentary state, the bottom missing; height: $2.6 \mathrm{~cm}$; bucket diameter: $2.0 \mathrm{~cm}$; bronze sheet thickness: $0,5 \mathrm{~cm}$. The piece was found in the central area of the tomb at the right of the human bones.

7. Disc-shaped bronze appliqué (Fig. 12/5) with a lug provided with a hole; diameter: $1-1.2 \mathrm{~cm}$; thickness: 0.05 $\mathrm{cm}$.

8. Chalcedony spheroid-shaped flattened bead (Fig. 12/6); height: $1.4 \mathrm{~cm}$, diameter: $2,1 \mathrm{~cm}$; hole diameter: 0,5 $\mathrm{cm}$. The piece was found in the soil filling the grave.

9. Limestone bead-amulet (Fig. 12/7) in the form of animal fang; length $2.4 \mathrm{~cm}$.

10-17. Eight cylindrical limestone (?) white beads (Fig. 12/8-15); length: $0.8-1.4 \mathrm{~cm}$, sectional diameter: 0,8 $\mathrm{cm}$.

18-20. Three amber beads (Fig. 12/16-18) having oval outline, flat; length: $1-2 \mathrm{~cm}$; width: 0,7 to $1,2 \mathrm{~cm}$; thickness; $0,5-0,7 \mathrm{~cm}$.

21-22. Two amber spheroid flattened beads (Fig. 12/19-20); diameter: 0,7-0,8 cm; height: 0,4-0,5 cm.

23. About quasi cylindrical bean (Fig. 12/21) of reddish coral; length: $1.6 \mathrm{~cm}$; diameter: $0.45 \mathrm{~cm}$.

24-27. Four polyhedral beads (Fig. 12/22-25) of iridescent dark blue glassy paste; length: $0,8-1,1 \mathrm{~cm}$, width: $0,6 \mathrm{~cm}$.

28. Polyhedral bead (Fig. 12/26) of white glassy paste; length: $0.55 \mathrm{~cm}$; width: $0,45 \mathrm{~cm}$.

29-30. Two rectangular-shaped flat beads (Fig. 12/2728) of white glassy paste, translucent; length: $1,2-1,3 \mathrm{~cm}$; width: $0,4 \mathrm{~cm}$; thickness: $0,3 \mathrm{~cm}$.

No.7-30 pieces were found in the soil filling the grave.

31-51. 21 integral (Fig. 12/29-49) and nine small size fragmentary beads of spheroid flattened form, made of gray- 
yellowish glassy paste; height: 0,2-0.3 cm; diameter: 0,3-0,4 $\mathrm{cm}$. The beads were found near the leg shanks.

Grave 4 (Fig. 5; 13/1-2) was at a distance of about $7,5 \mathrm{~m}$ south-south-west of the tomb 1 and about $3 \mathrm{~m}$ westnorth-west of the tomb 2 . The burial pit was surprised at the depth of 1,04 $\mathrm{m}$ from the current level of the ground and it had a depth of $1,25 \mathrm{~m}$ from the current ground surface and 0,21 from the identification level, being oriented on north-south direction. The pit was rectangular with rounded corners and had the dimensions of $0,89 \times 1,65 \mathrm{~m}$. The skeleton, belonging to a child of 3-5 years (infant I), rotted in bulk; only ten remains of the skull have been preserved, three teeth and three fragments from femurs diaphyseals.

Inventory:

1-3. Three small flattened spheroid beads (Fig. 13/35) of gray-yellowish translucent

glassy paste found in the tomb filling; diameter: 0,3 $\mathrm{cm}$; height: $0,2 \mathrm{~cm}$.

Grave 5 (Fig. 5 ; 14) was discovered in the eastern edge of the excavation, at a distance of about $24 \mathrm{~m}$ east-south-east of the tomb 1 and about $5 \mathrm{~m}$ east-north-east of the northeastern corner of the trench of cult. The grave was discovered at the level of $1,07 \mathrm{~m}$ from the current ground surface and had a depth of 0,10 $\mathrm{m}$ from the identification level, being oriented from north to south. Rectangular-shaped, with rounded corners, the funerary pit had the dimensions of $0,58 \times 1,55 \mathrm{~m}$. The grave was ravaged in antiquity, the skull and some postcranial bones disappearing. According to the anthropological conclusion, the skeleton belonged to a woman's age at death of 20 years (adultus or maturus).

The tomb had no goods.

Cult complex (Fig. 5; 15) was reported in the eastern half of the excavation at a depth of about 1,01 to $1,07 \mathrm{~m}$ from the current ground surface on the background of yellow sterile clay and represent a rectangular area (the north-west corner could not be observed), north-north-east - southsouth-west oriented, bordered by recessed ditches in sterile soil, which is interrupted in the south forming an entry.

The complex presented on the outside the following sizes: north side - 9,9 m; east side- $9.4 \mathrm{~m}$; west side- $8.3 \mathrm{~m}$; south side from west- $4.8 \mathrm{~m}$; south side from east $-3,7 \mathrm{~m}$; entrance $-1,8 \mathrm{~m}$. The ditches had the wide of $0,7-0,9 \mathrm{~m}$, walls vertical or slightly oblique, nearly right bottom and depth varying between $0.20 \mathrm{~m}$ and $0,35 \mathrm{~m}$ from the identification level. The ditches filling consisted of dark-gray soil.

A fragment of the skull of a human skeleton and several pieces from a large hand-made jar were discovered in the ditches from the eastern and south-eastern parts of the complex (Fig. 16).

According to the wall thickness of the bone, the anthropologist Angela Simalscik assigned the skull, with probability, to a male individual of mature age (between 30 and 60 years).

The jar (Fig. 17) was worked by hand from coarse paste, with crushed shards, pebbles and sand in the texture and uneven burned, getting a brown-brick red colour with blackish spots. The vase had a bulging body, with a maximum diameter at the top, high splaying edge and flat bottom; height: about 44-46 cm; mouth diameter: $25 \mathrm{~cm}$; maximum diameter: $28 \mathrm{~cm}$; bottom diameter $15 \mathrm{~cm}$.
In addition to the described above cult complex with ditches and an entry, in the square $13 \mathrm{H}-16 \mathrm{H}$, at a depth of about $1,05 \mathrm{~m}$ from the current ground surface, a portion of ditch has been reported with the length of about 7,5 m, width of $0,6-0,8 \mathrm{~m}$ and depth of about 0,5 to $0,15 \mathrm{~m}$ from the identification level, oriented on west-northwest - eastsoutheast direction. The ditch had slightly oblique walls and right bottom and the filling consisted of gray soil without archaeological remains. Judging from the orientation and position in the excavation, it is possible that the ditch was part of the worship complex, being joined with the ditch from the northern side of the respective construction.

\section{FUNERAL RIT AND RITUALS}

As mentioned above, in the result of the rescue research at Medeleni from spring of 2015, there were discovered five burial tombs and a complex with ritual characteristics, belonging to a large area Sarmatian plan cemetery, the dimensions of which will be determined by future investigations. Nev e rtheless, judging from the satellite images and orthophotos and from prospect research data, this necropolis appears to be larger than the Sarmatian cemetery adjoining Petreşti, where 46 tombs and 35 earth constructions bordered by ditches were discovered. At the same time, it should not be excluded that some of the eight tumuli in the necropolis at Me deleni include Sarmatian tombs as well, principal or secondary, especially that, judging from aerial photos and satell i te images, some mounds seem to be provided with ritual ditches, as was attested at some Sarmatian tumuli investigated by excavations (e.g. at (Corpaci) $)^{5}$.

Regarding the graves arrangement in the excavation, we mention that they are located rarely and are spread over the entire uncovered surface relatively even, namely two in the centre and one at north, west and east edges (Fig. 5). In addition, in the western part of the excavation the cult complex bounded by ground ditches was also signalled.

Like the rest of Sarmatian complexes studied so far, the rite of five tombs discovered at Medeleni is inhumation. Indications of any mounds of earth above complexes were not observed, all the graves being flat. In this context, we mention that, according to the Vasile Grosu's calculations, discovered in the plane necropolises Sarmatian graves predominate in the region between Prut and Dniester over secondary funerals under mounds of old ages or the main ones from the Sarmatian barrows, representing approximately $54 \%$ of all complexes ${ }^{6}$.

The graves had middle depths between 1,07 and 1,74 m from the current surface of the ground. Having been dug in sterile yellow soil, pits could be observed and marked at all complexes. They were rectangular with rounded corners, their width varying between 0,58 and $1,0 \mathrm{~m}$, and length between 1,65 and 2,31 m (Fig. $5 ; 6 ; 8 ; 10 ; 13 ; 14$ ). As is well known, rectangular pits, with greater or lesser width, have become a characteristic of the Sarmatian tombs far back as the late Sarmatian period on the entire area inhabited by them, over several centuries ${ }^{7}$.

GROSU 1979, 250-255.

GROSU 1995, 134

BÂRCĂ 2006, 40. 
All complexes were generally oriented from north to south, with some minor deviations to west. Related to this element of the funerary practices, it must be said that a north-south orientation of tombs was characteristic in the epoch of Roman domination for all Sarmatian populations from the north-pontic space, just like deposition of the defunct lying on the back with hands placed along the body ${ }^{8}$.

A common feature of the graves from Medeleni investigated so far is their disturbing in old age, probably according to a ritual, harder to decipher today. Two tombs (Nos. 1 and 3) had the upper parts of the skeletons destroyed, only the legs being preserved in anatomical position, which were adjacent and stretched from north to south. The other two graves (no. 2 and 5) were totally torn, not even the inferior members stored in anatomical connection. As for the grave no. 4 belonging to a child of 3-5 years, from the skeleton of which only a few insignificant remnants were preserved, we cannot know exactly whether the bones had disappeared because of their fragility or the grave exhumation in antiquity. We note, in this context, that tombs disturbed in old age, attributed to ritual practices, were also reported in the Sarmatian necropolis from Petreşti, but they constitute a small percentage there, most complexes are nevertheless undisturbed. A similar situation as at Medeleni was attested, instead, in the Sarmatian cemetery at Bădragii Noi-La Stâncă, where seven of the eight discovered graves were destroyed in antiquity. It is important to note that here some burials were torn completely, in others only the top of the skeletons was disturbed, shank bones remaining in situ in prone position, on which we could determine the orientation of the graves that were either north-west - south-east or north-south ${ }^{9}$. In addition, it has been observed that, as in the necropolis studied by us, original sepulchral pits were not damaged during exhumation, this probably due to the fact, that at the moment of destroying, the tombs were well marked on the surface of the ground ${ }^{10}$.

According to the anthropological measurements, the four tombs discovered at Medeleni belong to adult women of different ages at death. Judging from discovered beads, the child buried in tomb no. 5 was also female. In this context, it is interesting to note that, unlike Medeleni graves, three of five, anthropologically determined burials of Sarmatian necropolis from Badragii Noi-La Stâncă, were attributed to male individuals, but two of them to children ${ }^{11}$.

We should also connect the complex, bounded by a ditch and provided with an entry, with ritual or worship practices used in the necropolis of Medeleni. We mention, that in the ditch from the eastern part of the complex several pieces of a hand-made jar-type vessel and a human skull fragment were discovered, their significance being difficult to estimate. Similar earth structures had been also reported in other Sarmatian plane necropolises between Prut and Dniester, such as, for instance, those of Petreşti, Cuconeştii Noi (cemetery 2), Bădragii Noi and Holmskoe ${ }^{12}$. The most complexes, numbering 35, had been discovered in the neighbouring cemetery Petreşti, where 19 constructions

8 BÂRCĂ/SYMONENKO 2009, 44-45.

KURCIATOV/BUBULICI 1998, 220-227.

10 KURCIATOV/BUBULICI 1998, 227.

1 KURCIATOV/BUBULICI 1998, 227.

12 GROSU 1995, 146 were rectangular and 16 circular, all being bounded by ditches ${ }^{13}$. One of these complexes was intersected in the north-east by a west-east-oriented linear ditch, as seems the earth construction from Medeleni had to be.

Six such rectangular complexes in the ground had been reported in the cemeteries at Cuconestii Vechi and Bădragii Noi. It is worth mentioning, that in most constructions archaeological material was not found. But a ceramic vase and a horse skull were discovered in a complex at Cuconestii Vechi, and in two ditches from Bădragii Noi numerous fragments of Roman amphorae.

As to the destination, in all probability, complexes bounded by ditches from Sarmatian necropolises represented places of cult, where certain rituals connected with the funeral worship were practiced. This supposition is propped up by the presence of amphorae shards in the ditches of the constructions from Bădragii Noi, which probably are the remains of the funerary feast. In addition to the described above cult complex with ditches and an entry, in the square $13 \mathrm{H}-16 \mathrm{H}$, at a depth of about $1.05 \mathrm{~m}$ from the current ground surface, a portion of ditch has been reported with the length of about $7.5 \mathrm{~m}$, width of $0.6-0.8 \mathrm{~m}$ and depth of about 0.5 to $0.15 \mathrm{~m}$ from the identification level, oriented on westnorthwest - east-southeast direction. The ditch had slightly oblique walls and right bottom and the filling consisted of gray soil without archaeological remains. Judging from the orientation and position in the excavation, this ditch could be part of the worship complex, being joined with the ditch from the northern side of the respective construction.

As mentioned above, in the result of the rescue research at Medeleni from spring of 2015, there were discovered five burial tombs and a complex with ritual characteristics, belonging to a large area Sarmatian plan cemetery, the dimensions of which will be determined by future investigations. Nevertheless, judging from the satellite images and orthophotos and from prospect research data, this necropolis appears to be larger than the Sarmatian cemetery adjoining Petreşti, where 46 tombs and 35 earth constructions bordered by ditches were discovered. At the same time, it should not be excluded that some of the eight tumuli in the necropolis at Medeleni include Sarmatian tombs as well, principal or secondary, especially that, judging from aerial photos and satellite images, some mounds seem to be provided with ritual ditches, as was attested at some Sarmatian tumuli investigated by excavations (e.g. at Corpaci).

Regarding the graves arrangement in the excavation, we mention that they are located rarely and are spread over the entire uncovered surface relatively even, namely two in the centre and one at north, west and east edges (Fig. 5). In addition, in the western part of the excavation the cult complex bounded by ground ditches was also signalled.

Like the rest of Sarmatian complexes studied so far, the rite of five tombs discovered at Medeleni is inhumation. Indications of any mounds of earth above complexes were not observed, all the graves being flat. In this context, we mention that, according to the Vasile Grosu's calculations, in the region between Prut and Dniester, Sarmatian graves, discovered in the plane necropole, predominate

\footnotetext{
13 GROSU 1995, 146, fig. 19.
} 
over secondary funerals under mounds of old ages or the main ones from the Sarmatian barrows, representing approximately $54 \%$ of all complexes.

The graves had middle depths between 1,07 and 1,74 $\mathrm{m}$ from the current surface of the ground. Having been dug in sterile yellow soil, pits could be observed and marked at all complexes. They were rectangular with rounded corners, their width varying between 0,58 and $1,0 \mathrm{~m}$, and length between 1,65 and 2,31 m. As is well known, rectangular pits, with greater or lesser width, have become a characteristic of the Sarmatian tombs far back as the late Sarmatian period on the entire area inhabited by them, over several centuries.

All complexes were generally oriented from north to south, with some minor deviations to west. Related to this element of the funerary practices, it must be said that a north-south orientation of tombs was characteristic in the epoch of Roman domination for all Sarmatian populations from the north-pontic space, just like deposition of the defunct lying on the back with hands placed along the body.

A common feature of the graves from Medeleni investigated so far is their disturbing in old age, probably according to a ritual, harder to decipher today. Two tombs (Nos. 1 and 3) had the upper parts of the skeletons destroyed, only the legs being preserved in anatomical position, which were adjacent and stretched from north to south. The other two graves (no. 2 and 5) were totally torn, not even the inferior members stored in anatomical connection. As for the grave no. 4 belonging to a child of 3-5 years, from the skeleton of which only a few insignificant remnants were preserved, we cannot know exactly whether the bones had disappeared because of their fragility or the grave exhumation in antiquity. We note, in this context, that tombs disturbed in old age, attributed to ritual practices, were also reported in the Sarmatian necropolis from Petreşti, but they constitute a small percentage there, most complexes are nevertheless undisturbed. A similar situation as at Medeleni was attested, instead, in the Sarmatian cemetery at Bădragii Noi-La Stâncă, where seven of the eight discovered graves were destroyed in antiquity. It is important to note that here some burials were torn completely, in others only the top of the skeletons was disturbed, shank bones remaining in situ in prone position, on which we could determine the orientation of the graves that were either north-west - south-east or north-south. In addition, it has been observed that, as in the necropolis studied by us, original sepulchral pits were not damaged during exhumation, this probably due to the fact, that at the moment of destroying, the tombs were well marked on the surface of the ground.

According to the anthropological measurements, the four tombs discovered at Medeleni belong to adult women of different ages at death. Judging from discovered beads, the child buried in tomb no. 5 was also female. In this context, it is interesting to note that, unlike Medeleni graves, three of five, anthropologically determined burials of Sarmatian necropolis from Badragii Noi-La Stâncă, were attributed to male individuals.

We should also connect the complex, bounded by a ditch and provided with an entry, with ritual or worship practices used in the necropolis of Medeleni. We mention, that in the ditch from the eastern part of the complex several pieces of a hand-made jar-type vessel and a human skull fragment were discovered, their significance being difficult to estimate. Similar earth structures have been also reported in other Sarmatian plane necropole between Prut and Dniester, such as, for instance, those of Petreşti, Cuconeştii Noi (cemetery 2), Bădragii Noi and Holmskoe. The most complexes, numbering 35, have been discovered in the neighbouring cemetery Petreşti, where 19 constructions were rectangular and 16 circular, all being bounded by ditches. One of these complexes was intersected in the north-east by a west-east-oriented linear ditch, as seems the earth construction from Medeleni had to be.

Six such rectangular complexes in the soil had been reported in the cemeteries at Cuconestii Vechi and Bădragii Noi. It is worth mentioning, that in most constructions archaeological material was not found. But a ceramic vase and a horse skull were discovered in a complex at Cuconestii Vechi, and in two ditches from Bădragii Noi - numerous fragments of Roman amphorae.

As to the destination, in all probability, complexes bounded by ditches from Sarmatian necropole represented places of cult, where certain rituals connected with the funeral worship were practiced. This supposition is propped up by the presence of amphorae shards in the ditches of the constructions from Bădragii Noi, which probably are the remains of the funerary feast ${ }^{14}$.

\section{INVENTORY TYPOLOGY}

Inventory caming from Sarmatian graves of Medeleni includes the following categories of materials: ceramic vessels, household tools, adornment goods and clothing items.

Ceramic vessels. Like in other cemeteries, Sarmatian pottery is one of the best documented inventory categories. Four clay containers were discovered at Medeleni by rescue excavations from 2015: one vessel in the grave 2 and in the cult complex and two items in the tomb 3 . Three handmade vases are Sarmatian and a container is worked on the wheel, representing a Roman import element.

The three handmade receptacles belong to as many types.

Type 1 comprises the ceramic vase (Fig. 9/1; 18, 1) discovered in the grave 2 ; the body is about bi-truncatedshaped, the bottom is flat and little relieved, the mouth narrower than the bottom and the low edge flaring on the outside; it is modelled of fine paste and burned in a reducing atmosphere, but incomplete, that's why is corroded. For the present, identical analogues to this container were not found among the Sarmatian antiquities in the space between Prut and Dniester rivers.

Type 2 is represented by a medium-sized mug (Fig. $11 / 2 ; 18 / 3$ ) with ovoid body, reverted rim and a flat bottom, slightly convex; the handle of the vessel is approximately rectangular in section, with the upper end caught to the shoulder and the lower one to the maximum diameter zone; it is handmade of relatively fine paste with small organic ingredients in composition and burned incompletely and unevenly, acquiring a light-brown colour, sometimes with gray spots. The container was found in the grave 3 , which ${ }^{14}$ GROSU 1995, 146. 
comprised a relatively reach inventory. According to $\mathrm{V}$. Barca's typology, the Medeleni mug falls into the type IV, dated in the second part of the $\mathrm{I}^{\text {st }}$ century $\mathrm{AD}^{15}$. A vessel of the similar shape, but with a zoomorphic handle presenting a boar or bear, was found in a Sarmatian tomb from Dumeni, dated in the second half of the $\mathrm{I}^{\text {st }}$ century - the beginning of the $\mathrm{II}^{\text {nd }}$ century $\mathrm{AD}^{16}$.

Type 3 includes the fragmented vase discovered in the cult construction trench. It is a large jar with bulging body having a maximum diameter at the top, high flaring rim and flat bottom. According to the V. Barca's classification, it falls into the type I of the vessels for preparation and storage of food, dated especially in the middle Sarmatian period (the $\mathrm{I}^{\text {st }}$ century-the $\mathrm{II}^{\text {nd }}$ mid-century AD $)^{17}$. After L. Oţa and V. Sarbu typology, it belongs to the type I of jars, dating in the II $^{\text {nd }}$-III ${ }^{\text {rd }}$ centuries $\mathrm{AD}^{18}$. This type of jars have been reported in the Dacian pottery centre from Roman times at Pruteni and in some settlements from the southern Prut-Dniester space $^{19}$, such as those from Mologa, Cișmichioi and Tomai, dated in the first centuries of the $\mathrm{I}^{\text {st }}$ millenary $\mathrm{AD}^{20}$.

Regarding the Roman ceramic vessel found in the tomb 3 , it is a small-size pitcher (Fig. 11/1; 18/2), having spheroid body, narrow neck and a short, slightly thickened and splayed rim, but the bottom flat, little in relief. The handle is worked from a strip, oval in section, being caught under the rim and at the top of the body. A similar size and shape pitcher, but with funnel-shaped mouth, was discovered in a Sarmatian tomb from Taraclia, framed in terms of cronology in the $\mathrm{I}^{\text {st }}$ century $\mathrm{AD}^{21}$

Household tools. This category of objects included three clay spindle whorls, discovered in tombs 1 (Fig. 7/28) and 3 (two items) (Fig. 12/1-2). All three pieces are approximately truncated in shape with straight or slightly concave base. A spindle whorl found in the tomb 3 presents a decoration of incised oblique lines. The pieces in question, related to the clothing craft manufacturing, is an attribute of the Sarmatian culture, as reported in each necropolis investigated more intensively by excavation.

Adornment items. Adornment goods, taken in their entirety, make up the largest category of tombs inventory from the Roman epoch at Medelni. But as object types, this category of pieces from the complex surveyed is not too varied, including pendants, a bell, a link and various types of beads.

Pendants make up an important category of adornment goods discovered in the ancient cemetery of Medeleni. As seen in other related necropole, pendants or amulets are less numerous and have a lower frequency in graves than the beads, but are very varied in shapes and materials. We distinguish the following types:

Type 1. Pendant (Fig. 7/3) in the form of an amphorette, provided with a suspension link and 13 chains.

\footnotetext{
BÂRCĂ 2006, 69, fig. 154, 2.

6 KURCEATOV/BUBULICI 2004; BÂRCĂ 2006, 70, fig. 52, 3.

17 BÂRCĂ 2006, 67, fig. 151, 1-4.

18 OȚA/SÂRBU 2009, 151, fig. 24, 11; 25, 11

19 VORNIC/TELNOV/BUBULICI/CIOBANU 2008, 76, fig. 27, 1, 2; 36, 19 ; 59,$11 ; 99 \mathrm{~A}, 7$

20 GUDKOVA 1999, 252, 253, fig. 3, 4, 7; SHCHERBAKOVA 1983, 158, fig.

V; VI, 3; SHCHERBAKOVA 1988, 92, 93, fig. 1, 2.

${ }^{21}$ BÂRCĂ 2006, 360-361, fig. 120, 6.
}

It has been found in the tomb 1 , in combination with various other inventory pieces, including items made of gold. Being an ornament of great artistic refinement, the pendant to which we refer is unique for the moment in the Prut-Dniester space. Similar, but not identical pieces, were discovered in some Sarmatian complexes from the Eastern part of the continent, such as, for example, pendants pair of Sladkovskij (Tatsinskij district, Rostov region), dated at the end of the It $^{\text {st }}$ century- beginning of the II $^{\text {nd }}$ century $\mathrm{AD}^{22}$. A pair of this kind ornaments for head, considered earrings, with two small handles of the birds-shaped vase, were reported in a Sarmatian tumulus tomb from Zakanalnij (Volgograd region), framed in terms of chronology in the $I^{\text {st }}$ century $\mathrm{AD}^{23}$.

Type 2 includes a prism-shaped gold pendant (Fig. 7/1) with hexagonal base and a suspension link, having an embedded prismatic piece with hexagonal base, made of colorless rock crystal. Identical analogies to this piece of adornment are not yet known. A similar gold pendant, but with a child tooth in the mount, was discovered in a Sarmatian tomb from the tumulus necropolis Valovij-I (Miasnikovskij district, Rostov region), dated in the $\mathrm{II}^{\text {nd }}$ century $\mathrm{AD}^{24}$

Type 3. Tubular pendant (Fig. 7/2) of greenish glass, having the ends sealed with a mount of gold, each being provided with a suspension link of gold strip with longitudinal grooving on the outer side. Perfect analogies to this piece are not known yet. A similar gold cylindrical pendant, provided with two ears located at the ends and decorated on the body with three cells in shape of stylized hearts filled with glass paste, was found in a Sarmatian tomb from Hrușca, dated in the second half of the $\mathrm{I}^{\text {st }}$ century $\mathrm{AD}^{25}$. Pendants with gold mountings provided with grip ears, which caught in the middle one agate or chalcedony barrel -shaped bead, were found in some Sarmatian complexes from the Volga basin, dated in the $\mathrm{I}^{\text {st }}$ century $\mathrm{AD}$ - early next century, namely Baranovka-I and Verbovskii-II ${ }^{26}$. A pendant with similar mountings, but embedding a prismatic piece of rock crystal with octagonal base, was reported in a Sarmatian tomb from Nagavskii-II (Volgograd region), framed chronologically in the second half of the $\mathrm{II}^{\text {nd }}$ century - the first part of the $\mathrm{III}^{\text {rd }}$ century $\mathrm{AD}^{27}$. Inside some of this type pendants, pieces of sulfur, remnants of medicinal herbs or wrapped material have been found ${ }^{28}$. We remember in the context, that the item from Medeleni contained inside a white substance, still to be determined. Apparently, these pendants-amulets were used to keep some substances for healing wounds and curing some diseases.

Type 4 comprises a bronze cylindrical bucket-shaped pendant (Fig. 12/4) found in the tomb 3. Bucket-shaped pendants, but made of iron sheet, were reported in several Sarmatian graves from the Prut-Dniester space, such as, for example, those of Bădragii Vechi, Holmskoe, Zirnești ${ }^{29}$ etc.

\footnotetext{
ZASETSKAYA 2008, 139.

3 MORDVINTSEVA/KHABAROVA 2006, 13, 105, cat. 109.

ZASETSKAYA 2008, 142.

GROSU 1986, 258-261, fig. 1; BÂRCĂ 2007, 320, fig. 65, 21.

MORDVINTSEVA/KHABAROVA 2006, 76-78, 89-90, cat. 15; 54

MORDVINTSEVA/KHABAROVA 2006, 115, cat. 140.

BÂRCĂ 2006, 135.

BÂRCĂ 2006, 133.
} 
In a Sarmatian tumulus grave from Mihailovka of Bugeac, dated in the second half of the $\mathrm{I}^{\text {st }}$ century - beginning of the $\mathrm{II}^{\text {nd }}$ century $\mathrm{AD}$, a few gold pendants-bucket, inlaid with green glass, were discovered ${ }^{30}$. Four pendants-bucket, including two gold and two iron, were found in the Sarmatian luxurious tomb of Sokolova Mogila tumulus from Kovalevka (Nikolaev region, Ukraine), framed chronologically in the Ist $^{\text {st }}$ century $\mathrm{AD}^{31}$.

Type 5 is represented by a bead-pendant (Fig. 12/7) of limestone in the form of a claw or animal fang, discovered in the tomb 3 in combination with various beads and other objects.

Bell. We also placed in the category of adornment goods the bronze bell, discovered on the soil surface, but which probably comes from a destroyed tomb. The piece is pyramidal, having four sides of the base extended by excrescences (only one was preserved) and a ring at the upper end. Being considered as pendants-amulets meant to ward off evil spirits and being carried around the neck or hanging from the belt or hand, bells are widespread in the Roman Empire, but also in the barbaric environment of the northern Black Sea in the $\mathrm{I}^{\text {st }}-\mathrm{III}{ }^{\text {rd }}$ centuries $\mathrm{AD}^{32}$. In the Sarmatian environment of the East-Carpathian space, this kind pieces, but of hemispherical or truncated form, have been attested at Mocra, Ştefăneşti, Taraclia and Giurcani ${ }^{33}$. Except Mocra item, which is worked of gold, other bells are of bronze. Bells of the same type as one, found in Medeleni, have been reported in the Sarmatian graves from Talmaza and Căscioarele, dated in the III ${ }^{\text {rd }}$ century $\mathrm{AD}^{34}$.

Link of bronze wire with proximal ends, found in the tomb 3, can be considered a piece of adornment as well (Fig. 12/3). These kind pieces, used either as temple rings or mounted to the belts for hanging different objects or as pieces of harness, occur relative frequently in the Sarmatian graves, being dated widely, throughout the existence of Sarmatian culture. Among geographically close analogies, we quote those from Braviceni, Mărculeşti, Codrul Nou ${ }^{35}$ etc.

Beads. At Medeleni, as in the rest of the Sarmatian cemeteries, beads represent the most common ornaments. In total, 106 of such pieces have been discovered in the tombs 1, 2, 3 and 4. Most of them belong to the group of glass beads of different colours, ordinary or decorated, plus agate, limestone, amber, chalcedony and coral pearls. Taking into account the material they are made of, the shape, size, colour or decor, beads are divided into several types and variants.

Type 1, best represented, includes 62 small-sized beads (Fig. 9/16-40, 12/29-49) of spheroid flattened form, made of gray-yellowish, yellow or gray-brown glass paste. The pieces were found in the graves 2, 3 and 4 . It is interesting to note, that the beads from the tomb 3 were near the shanks, where they were used as garb objects, adorning, probably, the clothes. Beans of this type probably are one of the most

\footnotetext{
30 BÂRCĂ 2006, 329-330.

31 KOVPANENKO 1986, 95,97.

32 SIMONENKO 2011, 111-113; SÂRBU/OȚA/VÎLCU/NEAGU/OPREA

2014, 34.

33 BÂRCĂ 2006, 138.

34 POPA 2009, 80, 90, fig. 1,1; SÂRBU/OȚA/VÎLCU/NEAGU/OPREA 2014, 131, fig. 12,5.

35 BÂRCĂ 2006, 111
}

widespread in the Sarmatian complexes, being dated in the $\mathrm{I}^{\text {st }}$-III ${ }^{\text {rd }}$ centuries $\mathrm{AD}^{36}$.

Type 2 comprises five polyhedral glass beads, four of which (Fig. 12/22-25) are dark-blue and one (Fig. 12/26) is white, found in the tomb 3.

Type 3. Four beads (Fig. 9/7-8, 12/27-28) of prismatic shape with rectangular base of white glass paste inside and greenish one in the outside.

Type 4 is represented by three beads (Fig. 9/9-11) in form of a pill made of pink glass paste, found in the tomb 2 .

Type 5 comprises 13 barrel-shaped agate beads (Fig. 7/15-27) discovered in the grave 1 near the neck of the deceased. Agate beads of the same form were reported in some tumulus graves at Bădragii Vechi, dating in the second half of the It $^{\text {st }}$ century - beginning of the next century ${ }^{37}$.

Type 6 includes 10 cylindrical limestone (?) beads (Fig. $9 / 4-5 ; 12 / 8-15)$ of white colour, found in the graves 2 and 3 .

Type 7. Three flat, oval-shaped amber beads (Fig. 12/16-18) discovered in the tomb 3. A flattened amber bead was found in the tomb 3 of tumulus 14 from Dumeni, a complex that contained, among other things, an iron sword and several iron arrowheads ${ }^{38}$.

Type 8 comprises two spheroid flattened beads (Fig. 12/19-20) of amber, discovered in the tomb 3. Small amber beads were found in a Sarmatian tomb at Dubăsarii Vechi, dated in the $\mathrm{I}^{\text {st }}$ century $\mathrm{AD}^{39}$.

Type 9. Flat amber bead (Fig. 9/6), with rectangular outline, found in the tomb 2.

Type 10 este is represented by a spheroid-shaped chalcedony flattened bead (Fig. 13/6), located in the tomb 3. Close analogs are known in the Sarmatian discoveries from Olăneşti ${ }^{40}$ and Bălţata ${ }^{41}$, dated in the II $^{\text {nd }}$ century AD. Several chalcedony spheroid beads were found in the free Dacian cemetery from Văleni, dated in the II $^{\text {nd }}$ century - the first half of the III ${ }^{\text {rd }}$ century $\mathrm{AD}^{42}$.

Type 11. Aproximate cylindrical bead (Fig. 12/21) of a reddish coral, found in the tomb 3 . Reddish coral beads were also found in the Sarmatian graves from Codrul Nou, Hancăuţi, Holmskoe, Bălțata ${ }^{43}$ etc. Some coral beads were found at Văleni in two cremation graves of the great necropolis from the Roman era ${ }^{44}$.

Representing mostly elements of import from the Roman provinces, beads discovered in the Medeleni funerary site find plentifully analogies in the ancient North-Pontic centers and in various Dacian and Sarmatian complexes from the eastern Carpathian area, dating in the I $^{\text {st }}$-III ${ }^{\text {rd }}$ centuries $\mathrm{AD}^{45}$.

Pieces of clothing. This category of objects is represented by 13 appliques, including 11 of gold and two of bronze. Gold appliques were found in the tomb 1, and the

\footnotetext{
TEMPELMANN-MACZYNSKA 1985, 29, group I, types 17-28 BUBULICI/MATVEEV 2014, 137.

7 BÂRCĂ 2006, 275-277, 280, 283, 287.

8 GROSU 1988, 84-85, fig. 3.

39 GROSU 1990, 42; BÂRCĂ 2006, 308-309.

KURCHATOV/BUBULICH 2003, 295, fig. 4, 6.

BUBULICI/MATVEEV, 2014, 135, fig. 5, 3.

IONIȚĂ/URSACHI 1988, 64, 96-97.

BUBULICI/MATVEEV, 2014, 135, fig. 5, 1 .

IONIȚĂ/RSACHI 1988, 64.

45 BICHIR 1973, 123-124; BÂRCĂ 2006, 139-144; ALEKSEEVA 1978 , passim.
} 
bronze ones in the tombs 2 and 3.

By form and the metal of which were made, they are grouped into four types:

Type 1 comprises seven gold triangular-shaped appliques (Fig. 7/8-14) made of gold sheet by punching, provided with a hole at the ends for gripping. In the Sarmatian environment from the Prut-Dniester space, gold appliqués of this type were discovered at Mihailovka and Turlaki as well ${ }^{46}$. In terms of time, triangular appliqués are dated in the second half of the $\mathrm{I}^{\text {st }}$ century-the $\mathrm{II}^{\text {nd }}$ century $\mathrm{AD}^{47}$.

Type 2 includes an integral appliqué and a fragment of another (Fig. 7/4-5) in rosette form with five petals made of gold foil by punching, having a bulging center, the edges of the petals being of granules, executed in au repousse technique, and holes at the ends of the petals for gripping. Gold rosette-shaped appliqués, but with six petals, were also repotted at Badragii Vechi (tumulus 7 , grave 2) and Porogi (tumulus 2, grave 2), complexes dating from the second half of the 1 st century AD - early next century ${ }^{48}$.

Type 3. Two gold tubular appliqués (Fig. 7/6-7), decorated with transversal grooves. Similar pieces worn either as appliqués or in necklaces have been reported at Belolesie (tumulus 9 tomb 1 ) and in the princely tombs from Porogi, dating from the second half of the 1st century $\mathrm{AD}^{49}$.

Type 4 is reprezented by two approximately discoidshaped bronze appliqués (Fig. 12/5), provided with pierced ears. Circular bronze appliqués, but with slightly protruding central part and provided with two symmetrically located grip holes, have been also observed in T 25 M 3 from Badragii Vechi, chronologically framed in the second part of the ${ }^{\text {st }}$ century $\mathrm{AD}^{50}$.

\section{GENERAL CONSIDERATIONS}

Although reduced in area and far to deliver sufficient data for solving multiple arising problems, the rescue archaeological research from Medeleni (Petreşti village, Ungheni district) conducted in the spring of 2015 , convincingly proved, that this archaeological site is particularly important for understanding the historicalarchaeological realities of the Middle Prut Plain in the first centuries of the new era. Scientific significance of the vestiges revealed in 2013 requires the most comprehensive study of the archeological complex concerned, the more that there is a danger of its destruction by various agricultural activities. Indubitable, an extensive and detailed research would allow establishing the limits and structure of the funeral site, getting knowledge about various aspects of the rites and customs of burial, a more precise chronological framing of the uncovered vestiges, as well as elucidating other aspects of ethno-cultural nature of this antique archaeological object on the left bank of the Prut.

Undoubtedly, an important, but also difficult issue, raised by the ancient cemetery from Medeleni, consists of its chronological classification. A brief overview on the revealed discoveries allows dating the site within the $\mathrm{I}^{\text {st }}-\mathrm{III}^{\text {rd }}$ centuries

46 BÂRCĂ 2006, 117.

47 MARCHENKO 1996, fig. 11, 15-21; BÂRCĂ 2006, 117.

48 BÂRCĂ 2006, 119, 276, 353, fig. 5, 7; 109, 4-4b.

49 BÂRCĂ 2006, 120, fig. fig. 27, 14-15; 106, 3.

50 BÂRCĂ 2006, 117, fig. 12,3-6.
AD. But a more detailed analysis of the inventory pieces with chronological value and of other elements might plead for a narrower dating, namely in the second half of the It century - the II $^{\text {nd }}$ century AD. Among inventory items with higher power of dating, gold pieces from the tomb 1 primarily stand out, namely the amphorette-shaped pendant, prismatic pendant, tube pendant and appliqués for decorating clothes. For example, head ornaments, such as amphorette-shaped pendants provided with chains, appear in the Sarmatian graves, dating from the second half of the $\mathrm{I}^{\text {st }}$ century - the first part of the $\mathrm{II}^{\text {nd }}$ century AD. The prismatic and tubular pendants, as well as the gold appliqués, are dated wider, namely in the second part of the $\mathrm{I}^{\mathrm{st}}$ century- the $\mathrm{II}^{\text {nd }}$ century AD. As for the inventory items or indexes, that support a later chronology of the site, they are represented by a handmade jar type vessel of large dimensions and the presence of the earth construction bounded by grooves, which are characteristic, mainly, for sites from the II ${ }^{\text {nd }}$ century- the first part of the III ${ }^{\text {rd }}$ century AD. Corroborating all archaeological data, we can date the cemetery or, better said, the researched group of graves from Medeleni, in the end of the $I^{\text {st }}$ century - the first half of the II ${ }^{\text {nd }}$ century AD.

Concerning ethno-cultural affiliation of the ancient cemetery from Medeleni, all the main characteristics, such as rite, funerary practices and inventory of discovered goods, support the attribution of the necropolis in question to the Sarmatian nomads of Iranian origin. To state precisely the tribes union, to which the human group buried on the Medeleni plateau belonged, is difficult, but at the current stage of research. We note in this context, that for the second part of the $I^{\text {st }}$ century - the $\mathrm{II}^{\text {nd }}$ century $\mathrm{AD}$, ancient written sources remember specially about the Roxolana tribes, that dwelt in the north-west-pontic regions, including the PrutDniester space, and who undertook a series of resonant attacks on the Roman Empire ${ }^{51}$. However, some researchers ascribe burial tombs with obvious eastern traits of northand north-west-pontic space from the chronological interval between mid- $1^{\text {st }}$ century AD - the first part of the II $^{\text {nd }}$ century $\mathrm{AD}$ to Alane tribes. These complexes include the princely burials from Olăneşti and Mocra ${ }^{52}$, as well as flat necropole with ditches from Palanca and Bădragii Noi ${ }^{53}$.

\section{REFERENCES}

ALEKSEEVA 1978

Alekseeva, E. M., Antichnye busy Severnogo Prichernomor'ya (Moskva: Nauka).

BÂRCĂ 2006

Bârcă, V., Istorie şi civilizaţie. Sarmaţii în spaţiul est-carpatic (sec. I a.Chr. - începutul sec. II p.Chr.) (Cluj-Napoca: Argonaut).

BÂRCĂ/SYMONENKO 2009

Bârcă, V./Symonenko, O., Călărății stepelor. Sarmațiii în spațiul nord-pontic (Cluj-Napoca: Mega).

BICHIR 1973

Bichir, Gh., Cultura carpică (București: Editura Academiei Republicii Socialiste România).

BUBULICI/MATVEEV 2014

Bubulici, V./Matveev, S., Un mormânt sarmatic descoperit la Bălțata (r. Criuleni). In: Studii de arheologie și istorie în

\footnotetext{
IONIȚĂ 2001, 668, 669; BÂRCĂ 2006, 260-262.

KURCHATOV/BUBULICH 2003, 306-308; BÂRCĂ 2006, 254.

KURCHATOV/BUBULICH 2003, 308.
} 
onoarea profesorului Gheorghe Postică (Chisinău), 133144.

COVALENCO 1993

Covalenco, S., Repertoriul monumentelor arheologice din r-nul Ungheni (manuscris). Arhiva Agenției Naționale Arheologice (Chișinău).

COVALENCO 2006

Covalenco, S., Repertoriul arheologic al raionului Ungheni, Pyretus II, 5-40.

KURCEATOV/BUBULICI 2001

Kurceatov, S., Bubulici, V., Morminte de nobili în necropola de la Petrești, Pyretus 1, 33-37.

GROSU 1979

Grosu, V. I., Sarmatskij kurgan u s. Korpach, Sovetskaya Arkheologiya 2, 250-255.

GROSU 1983

Grosu, V. I., Novye sarmatskie pamyatniki na territorii Moldavii (dopolnenie $\mathrm{k}$ arkheologicheskoj karte MSSR), Arkheologicheskie issledovaniya v Moldavii v 1979-1980 g., 28-52.

GROSU 1986

Grosu, V. I., Sarmatskoe pogrebenie v Podnestrov'e, Sovetskaya Arkheologiya 1, 258-251.

GROSU 1990

Grosu, V. I., Khronologiya pamyatnikov sarmatskoj kul'tury

GROSU 1995

Dnestrovsko-Prutskogo mezhdurech'ya (Kishinev: Știința).

Grosu, V., Sarmaţii în spaţiul geto-dacic răsăritean, Arheologia Moldovei XVIII, 133-186.

GUDKOVA 1999

Gudkova, A. V., I-IV vv. v Severo-Zapadnom Prichernomor'e,

IONIŢĂ 2001 Stratum plus 4, 235-404.

Ioniţă, I., Sarmaţii. In: Istoria românilor. Vol. II. Daco-romani, romanici, alogeni (Bucureşti: Editura Enciclopedică), 663-678.

IONIȚĂ/URSACHI 1988

Ioniță, I./Ursachi, V., Văleni. O mare necropolă a dacilor liberi (Iași: Junimea).

KOVPANENKO 1986

Kovpanenko, G.T., Sarmatskoe pogrebenie I v.n.e. na Yuzhnom Buge (Kiev: Naukova dumka).

KURCHATOV 1989

Kurchatov, S. I., Novye materialy iz raskopok sarmatskogo i chernyakhovskogo mogil'nikov v s. Petresht' MSSR, In: Problemy skifo-sarmatskoj arkheologii Severnogo Prichernomor'ya (Zaporozh'e), 74-75.

KURCHATOV/BUBULICH 2003

Kurchatov, S. I./Bubulich,V.G., «Sarmatskoe pogrebenie iz kurgana u s. Oloneshty» - 40 let spustya. In: Interferenţe cultural-cronologice în spaţiul nord-pontic (Chișinău: Editura Centrului Poligraf USM), 285-312.

KURCHATOV/BUBULICH 2004:

Kurchatov, S. I./Bubulich,V.G., Obraz medvedya v sarmatskoj kul'ture Severo-Zapadnogo Prichernomor'ya. Karpatika, 31, 128-143.

\section{KURCIATOV/BUBULICI 1997}

Kurciatov, S./Bubulici, V., Necropola de la Bădragii Vechi şi problema fazei finale a culturii sarmatice. In: Vestigii arheologice din Moldova (Chişinău: Tipografia Academiei de Ştiinţe RM), 220-234.

KURCEATOV/VORNIC 2005

Kurceatov, S., Vornic,V., Un mormânt cu amforă romană din necropola de la Petrești (Ungheni), Tyragetia XIV, 87-95.

\section{MARCHENKO 1996}

Marchenko, I. I., Siraki Kubani (po materialam kurgannyh pogrebenij Nizhnej Kubani) (Krasnodar).

MORDVINTSEVA/KHABAROVA 2006

Mordvintseva, V., Khabarova, N., Drevnee zoloto Povol'zh'ya (Simferopol': Tarpan).

\section{OȚA/SÂRBU 2009} POPA 2009 Oța, L./Sârbu,V., Sarmații din județul Brăila (Brăila: Istros).

Popa, A., Consemnări asupra mormântului de la Talmaza și a inventarului lui. Notă despre răspândirea evantaielor romane în Barbaricum-ul European, Ephemeris Napocensis XIX, 79-108.

SÂRBU/OȚA/VÎLCU/NEAGU/OPREA 2014

Sîrbu,V./Oța, L./Vîlcu,A./Neagu, M./Oprea,V., Sudul Munteniei în secolele I a. Chr. - III p.Chr. Sarmați, Daci, Romani (Brăila: Istros).

\section{SHCHERBAKOVA 1983}

Shcherbakova, T. A., Raskopki poselenij pozdnerimskogo vremeni u s. Chishmikioj. Arkheologicheskie issledovaniya $v$ Moldavii v 1979-1980 gg. (Kishinev: Știința), 151-171.

\section{SHCHERBAKOVA 1988}

Shcherbakova, T. A., Keramicheskij kompleks poseleniya III-IV vv. u s. Tomaj. Arkheologicheskie issledovaniya $v$ Moldavii v 1983 g. (Kishinev: Știința), 91-100.

\section{SIMONENKO 2011}

Simonenko, A.V., Rimskij import u sarmatov Severnogo Prichernomor'ya (Sankt-Peterburg: Nestor Istoriya).

\section{TEMPELMANN-MACZYNSKA 1985}

Tempelmann-Maczyńska, M., Die perlen der römischen Kaiserzeit und der frühe Phase der Völkervanderungszeit im mitteleuropischen Barbaricum (Mainz am Rhein: Philipp Von Zabern).

\section{VORNIC/TELNOV/BUBULICI/CIOBANU 2008}

Vornic, V./Telnov, N./Bubulici, V./Ciobanu, L., Pruteni. Un centru de olărie dacic din epoca romană (Chișinău: Academia de Ştiinţe a Moldovei).

VORNIC/BUBULICI/POPOVICI 2015

Vornic, V./Bubulici, V./Popovici, S, Date preliminare privind necropola sarmatică de la Medeleni (com. Petrești, r-nul Ungheni), Arheologia Preventiva în Republica Moldova, II, 59-72.

\section{ZASETSKAYA 2008}

Zasetskaya, I. P., Sokrovishcha sarmatov, Katalog vystavki, $K$ 100-letiyu so dnya rozhdeniya akademika Borisa Borisovicha Piotrovskogo (Sankt-Peterburg - Azov). 

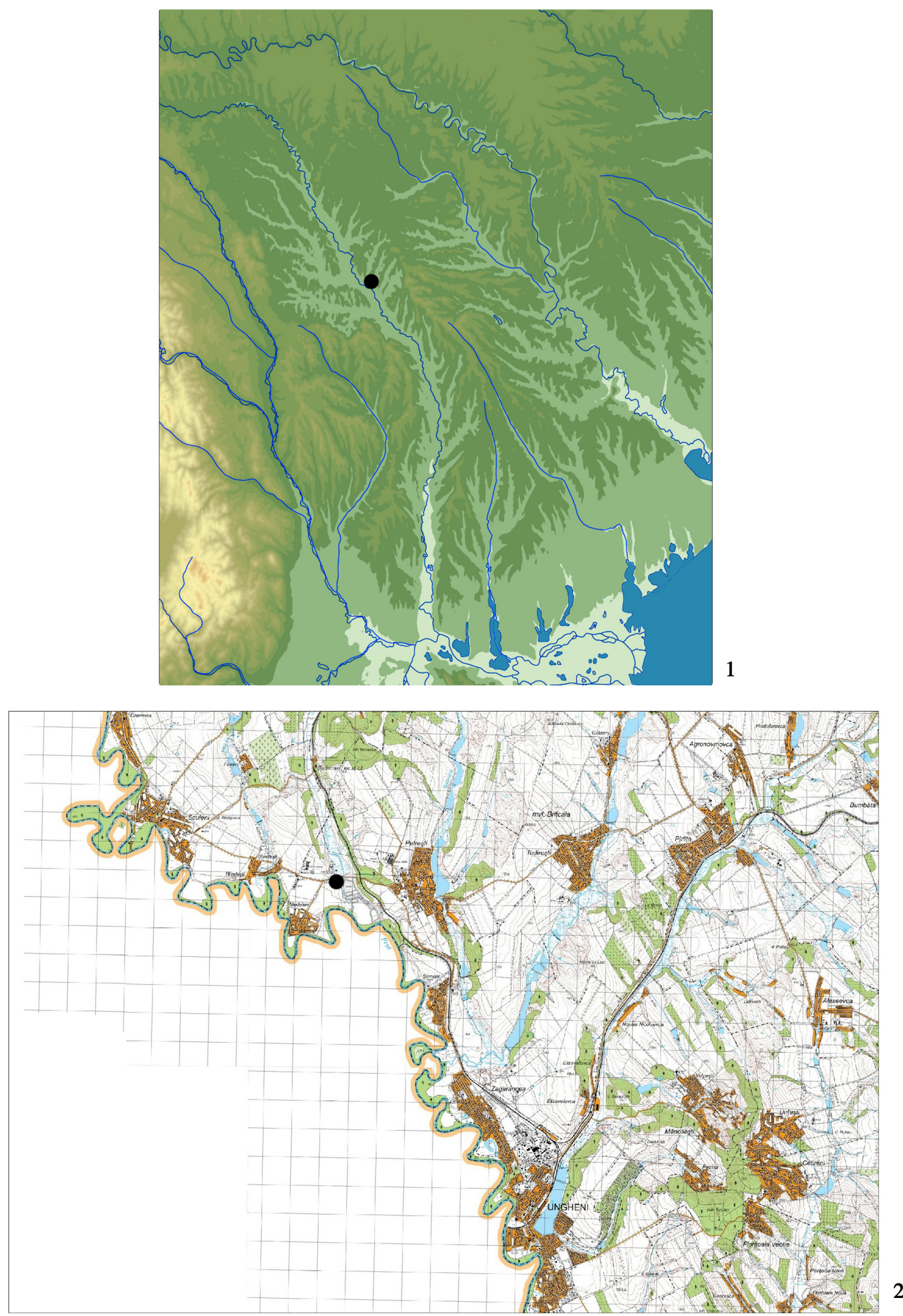

Fig. 1. Geographical location and topography of the archaeological site of Medeleni, Petreşti comune, Ungheni district. 

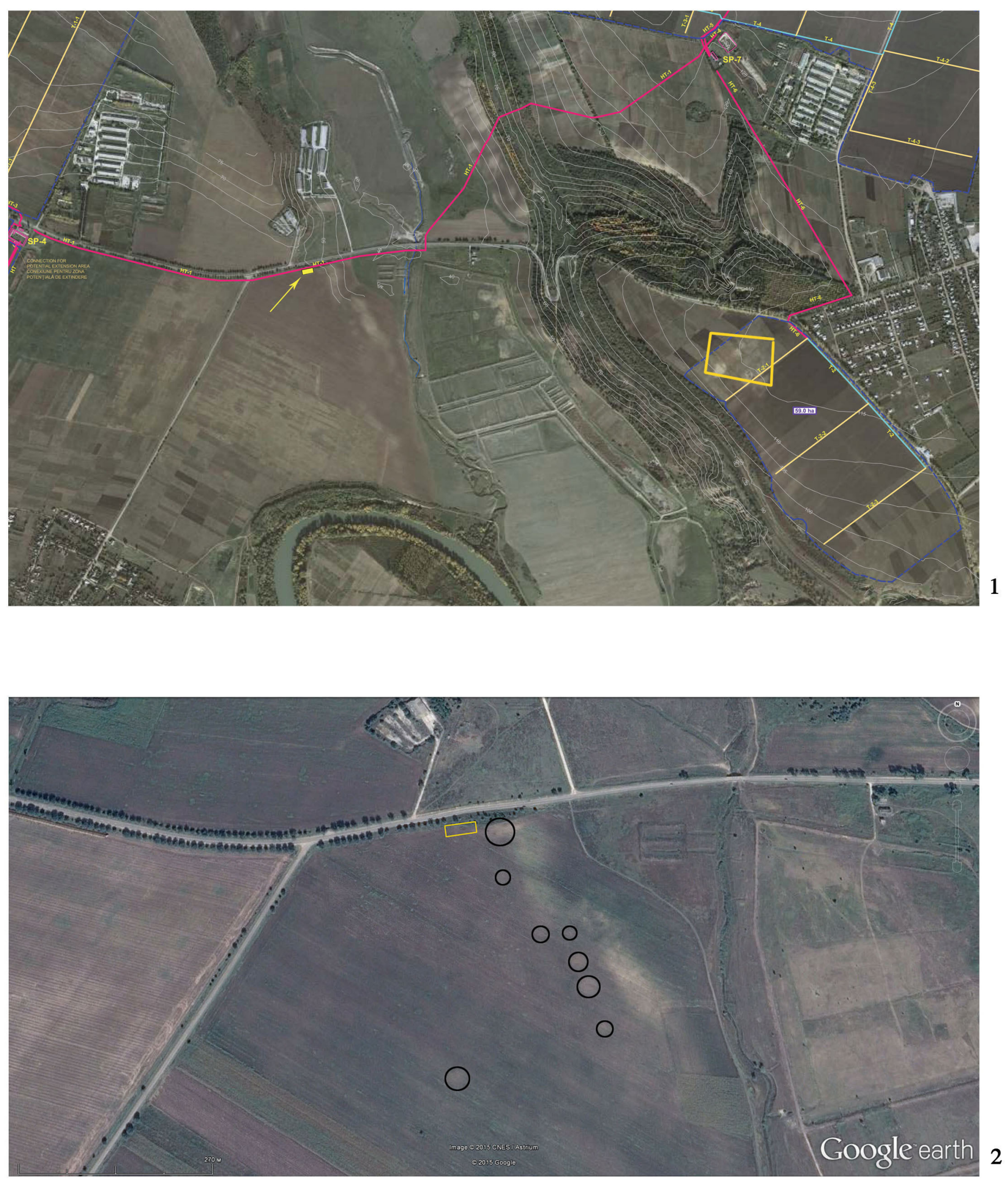

Fig. 2. Satellite images of the archaeological site from Roman times at Medeleni and Petreşti, Ungheni district.

32 Journal of Ancient History and Archeology No.3.3/2016

\section{Studies}

Google earth

.



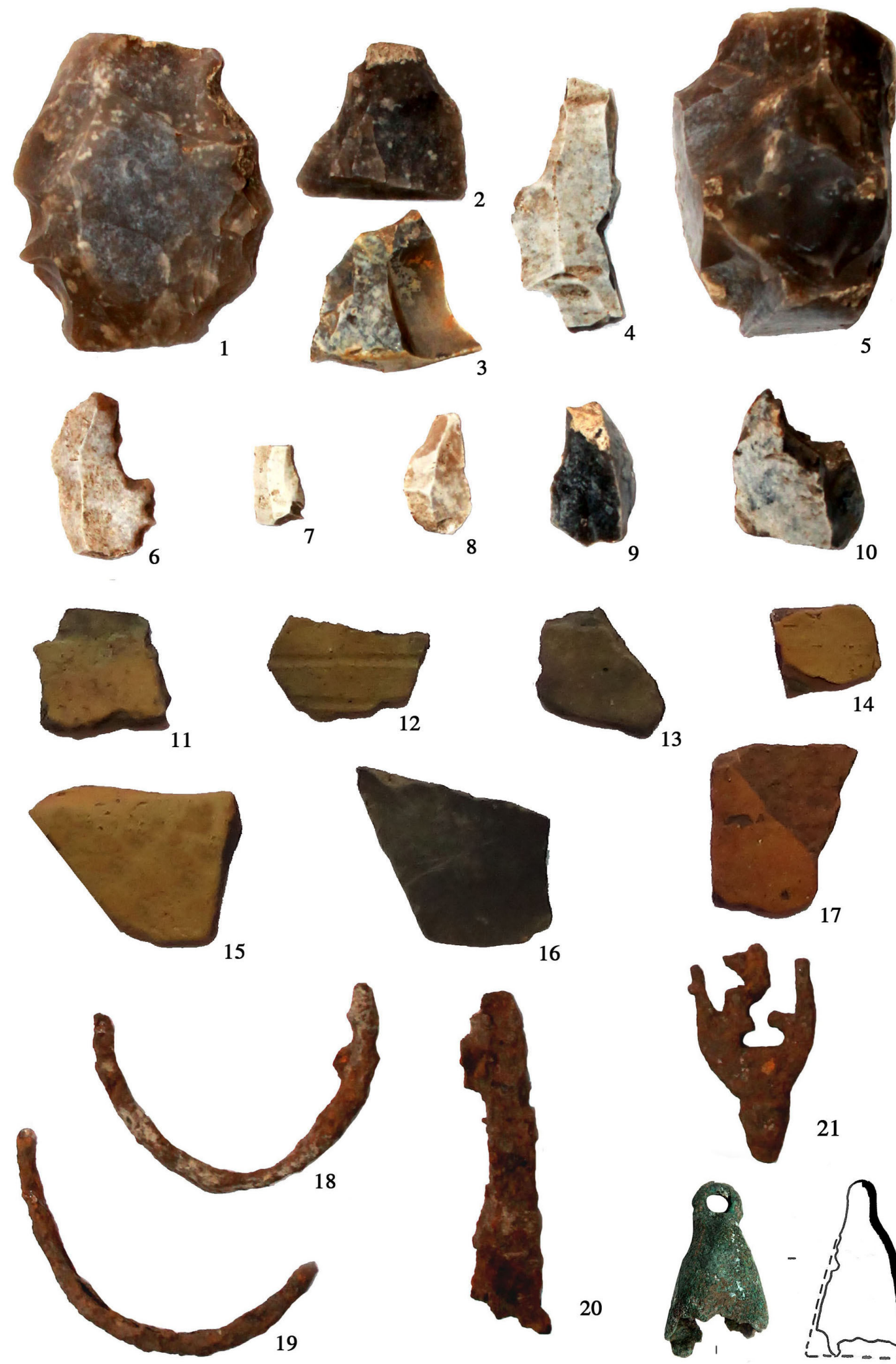

20
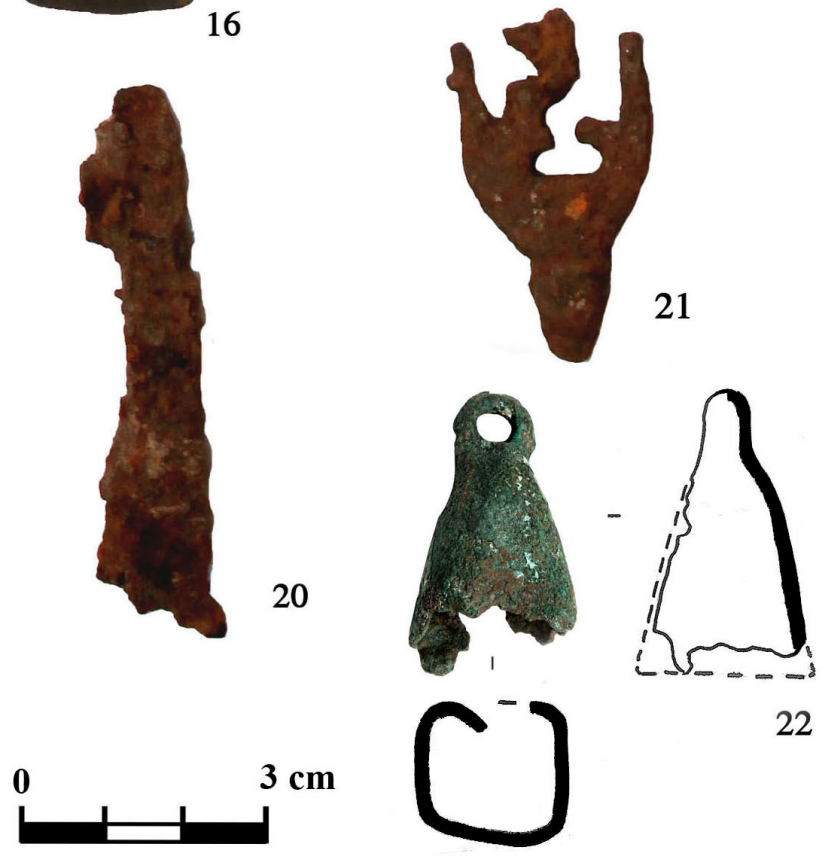

Fig. 3. Pieces of flint (1-10), pottery fragments (11-17), iron objects (18-21) and a bronze bell (22) discovered during surface investigation on the archaeological site of Medeleni. 
Studies
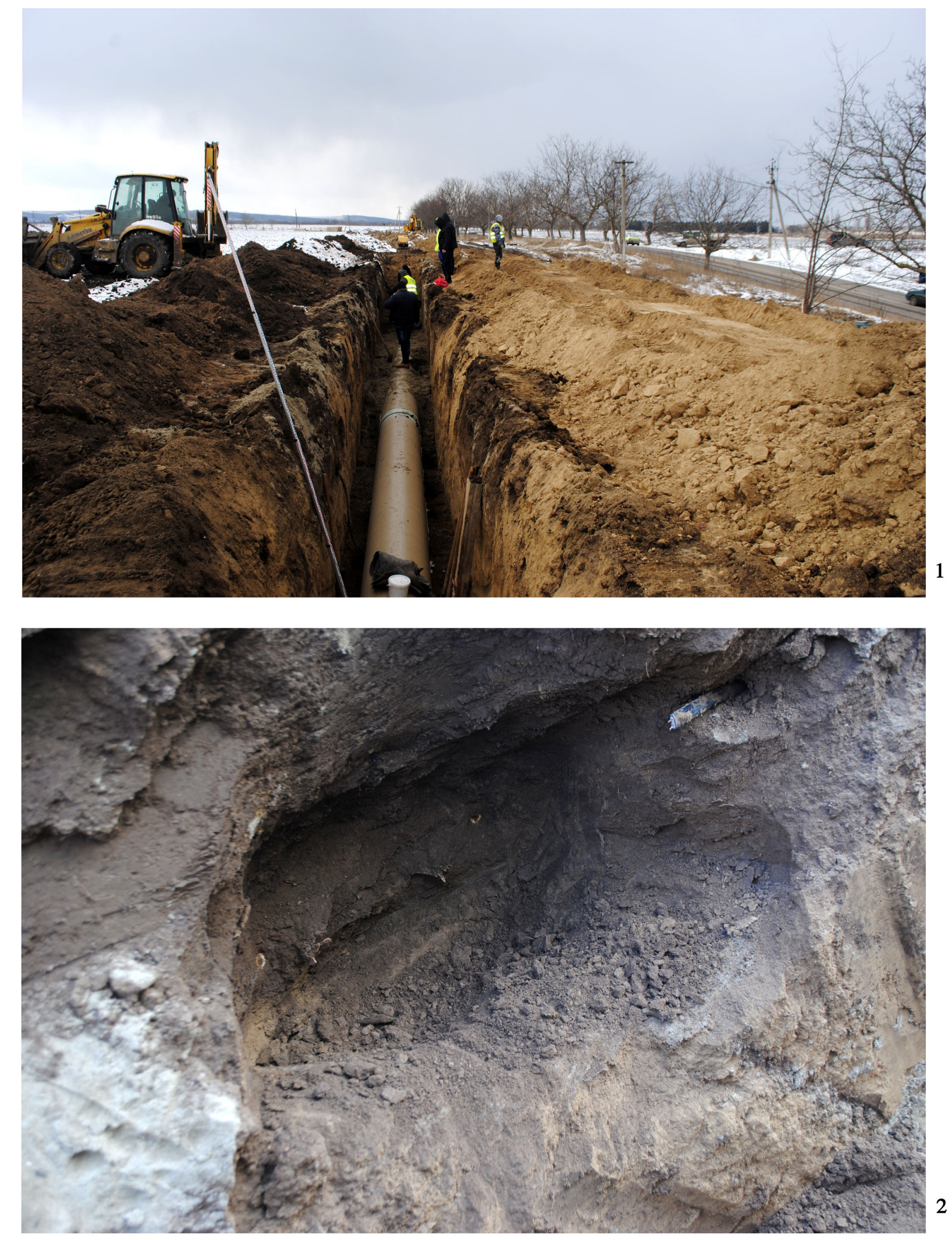

Fig. 4. Images of the ditch irrigation system and of the grave 1 (photo V. Popovici). 


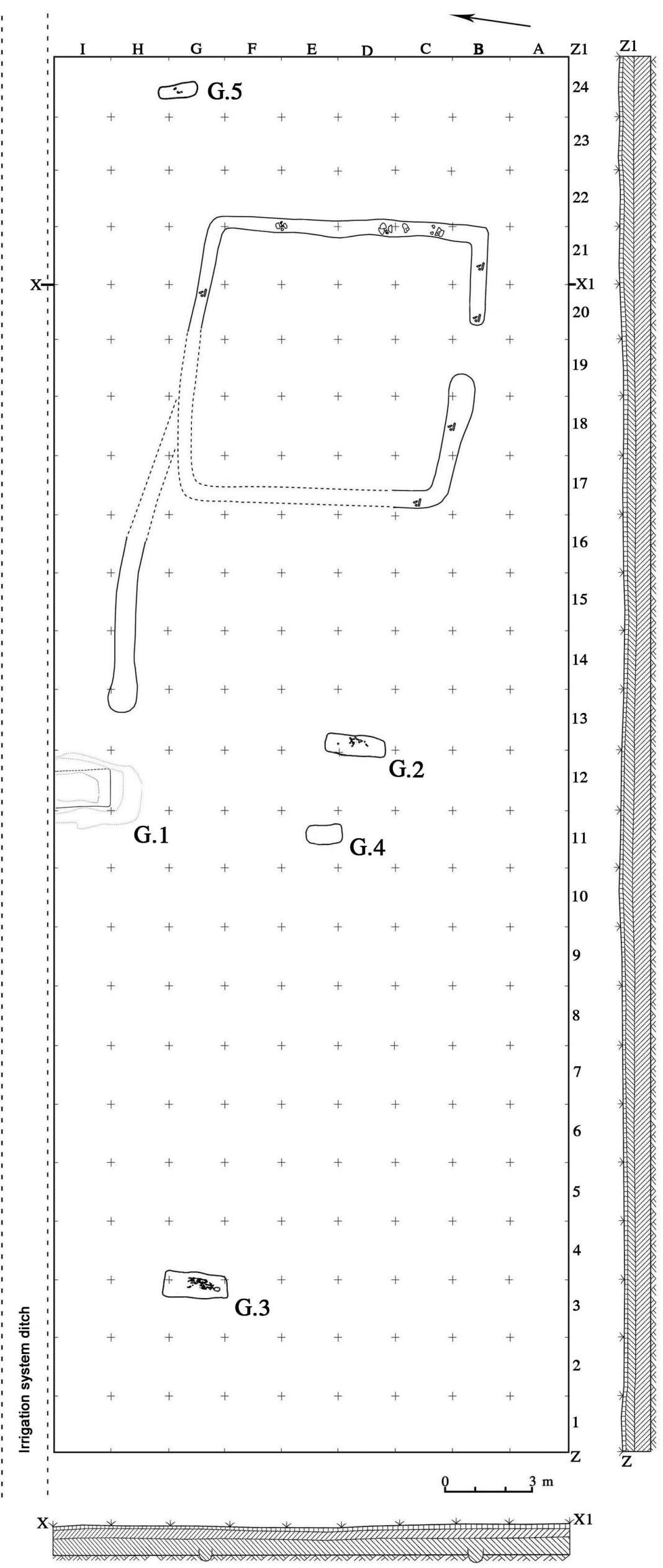

Fig. 5. Section I, plan and sections. 

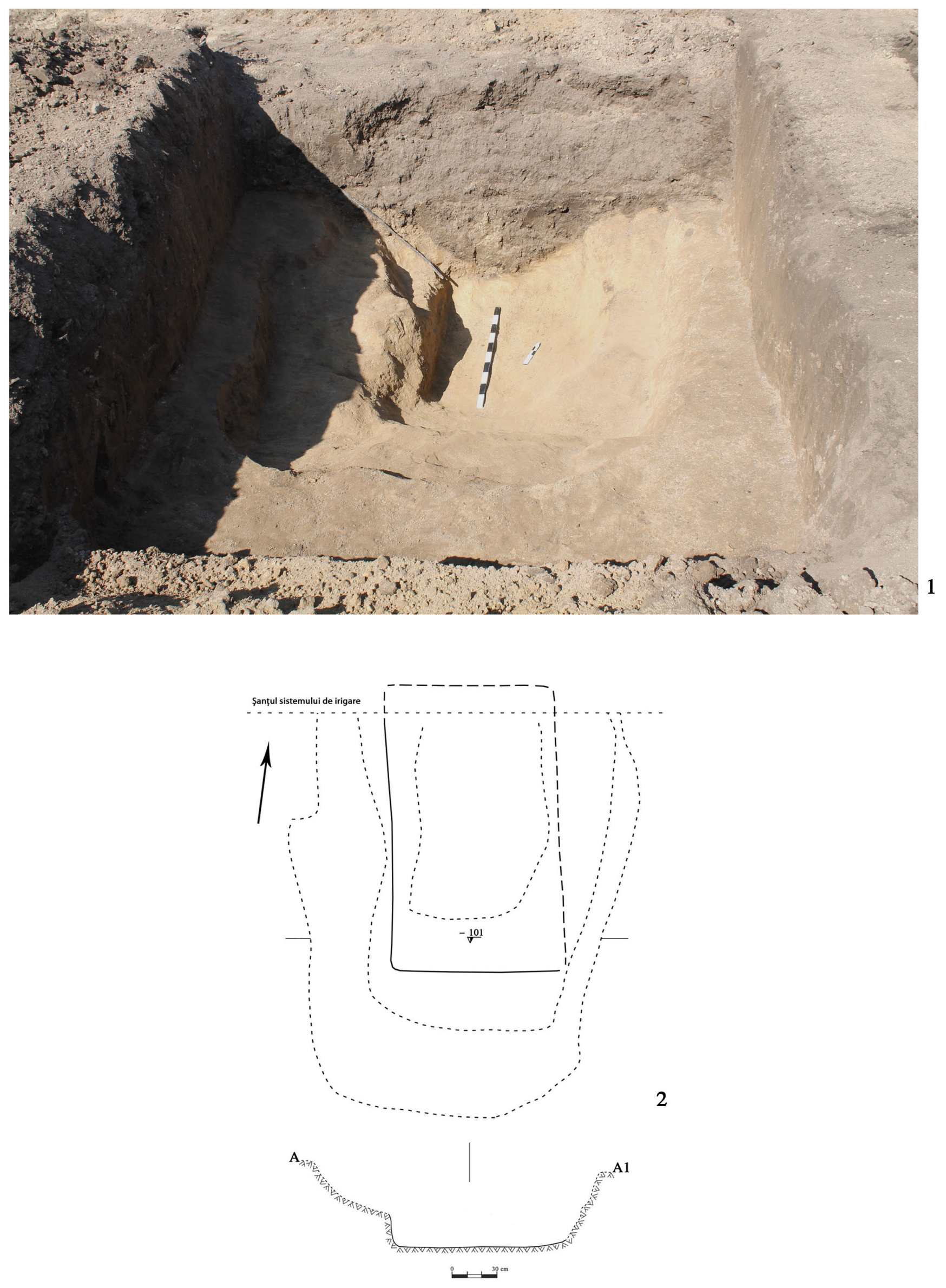

Fig. 6. Grave 1, plan and section. 

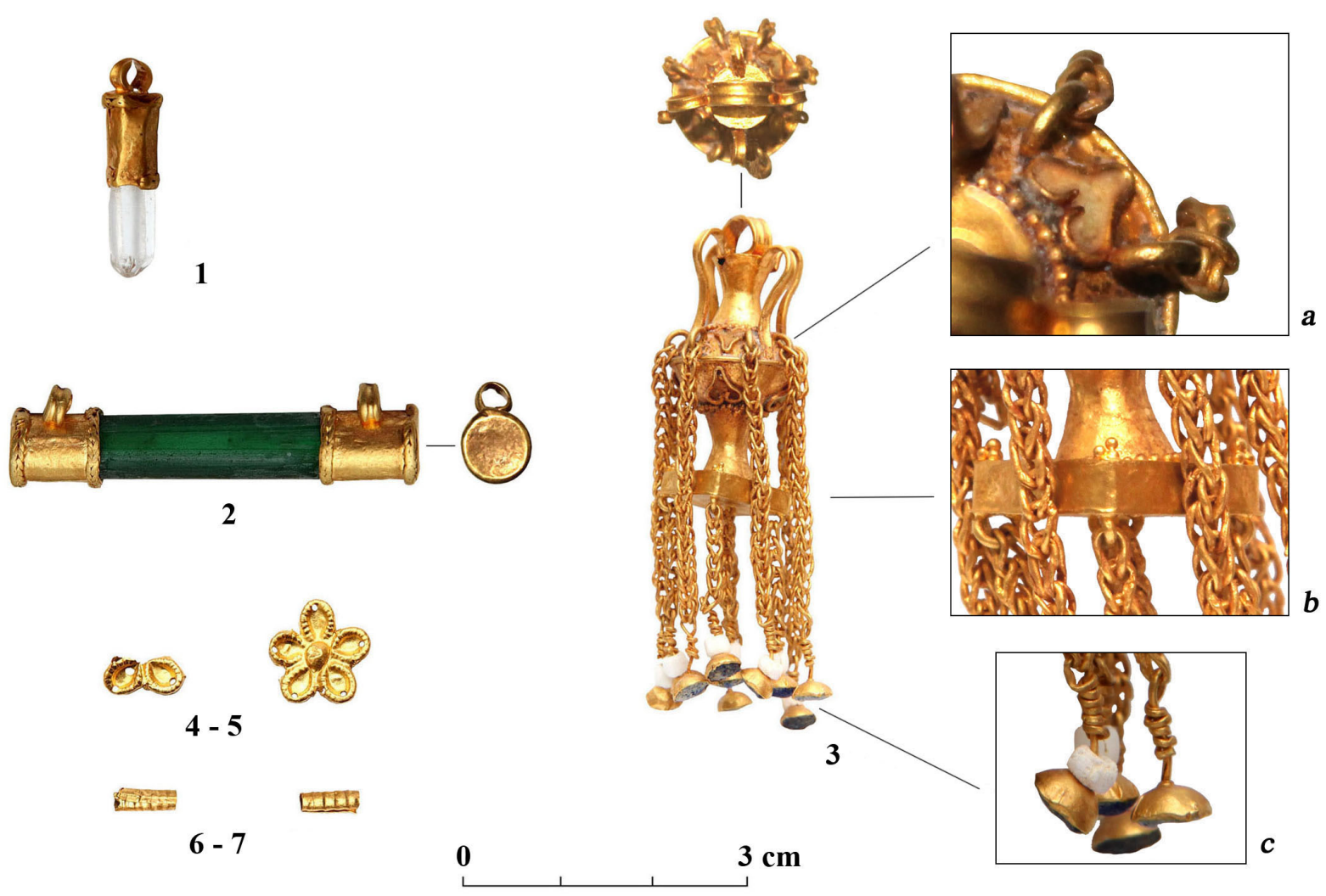

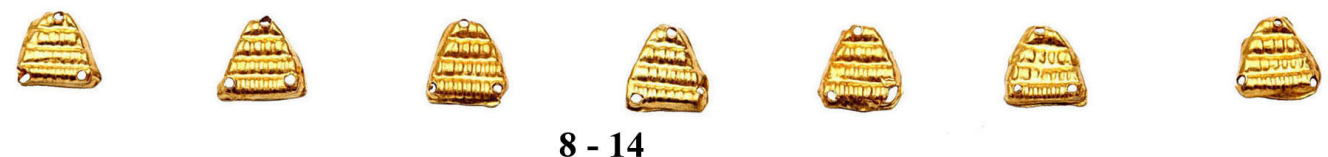

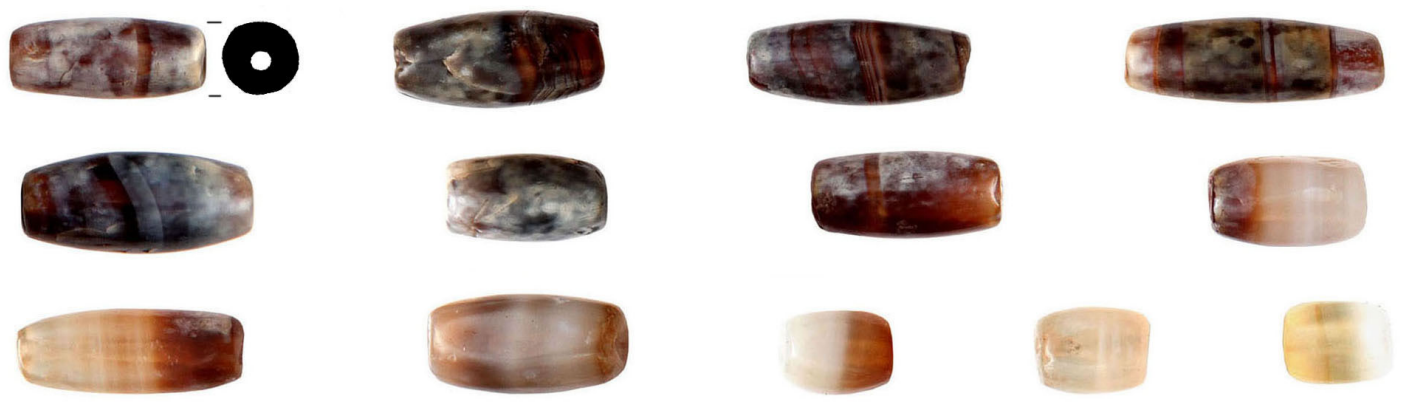

$15-27$
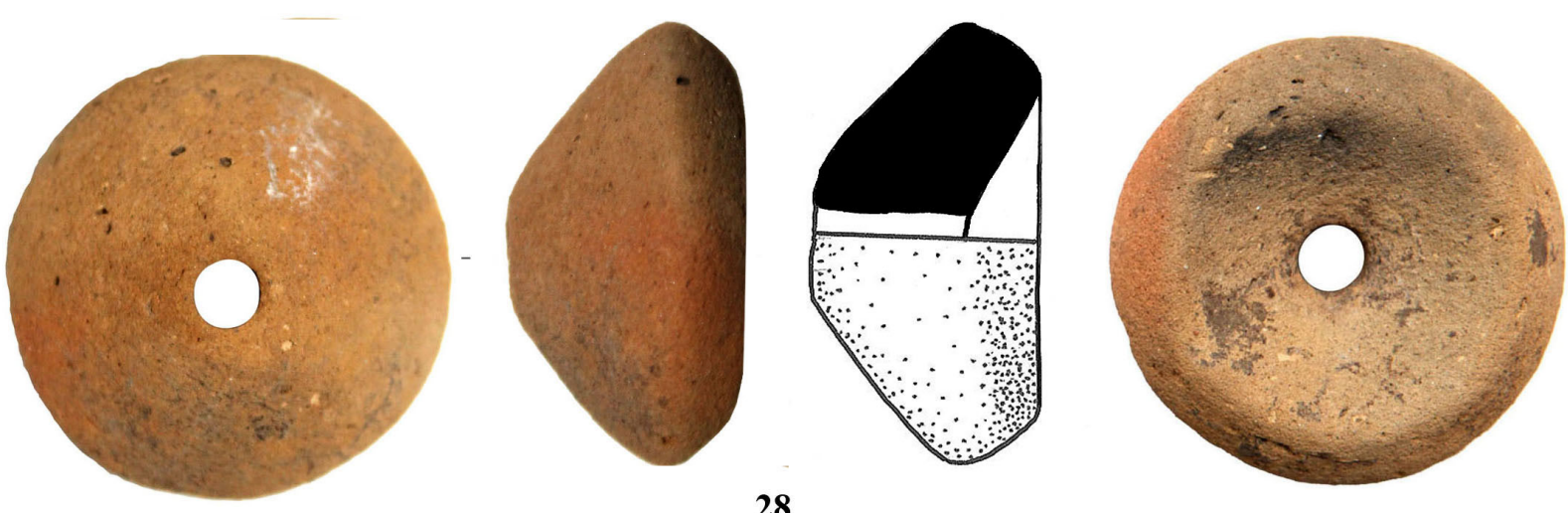

Fig. 7. Grave 1 inventary; 1-14, pieces of gold; 15-27, agate beads; 28, clay spindle-whorl. 

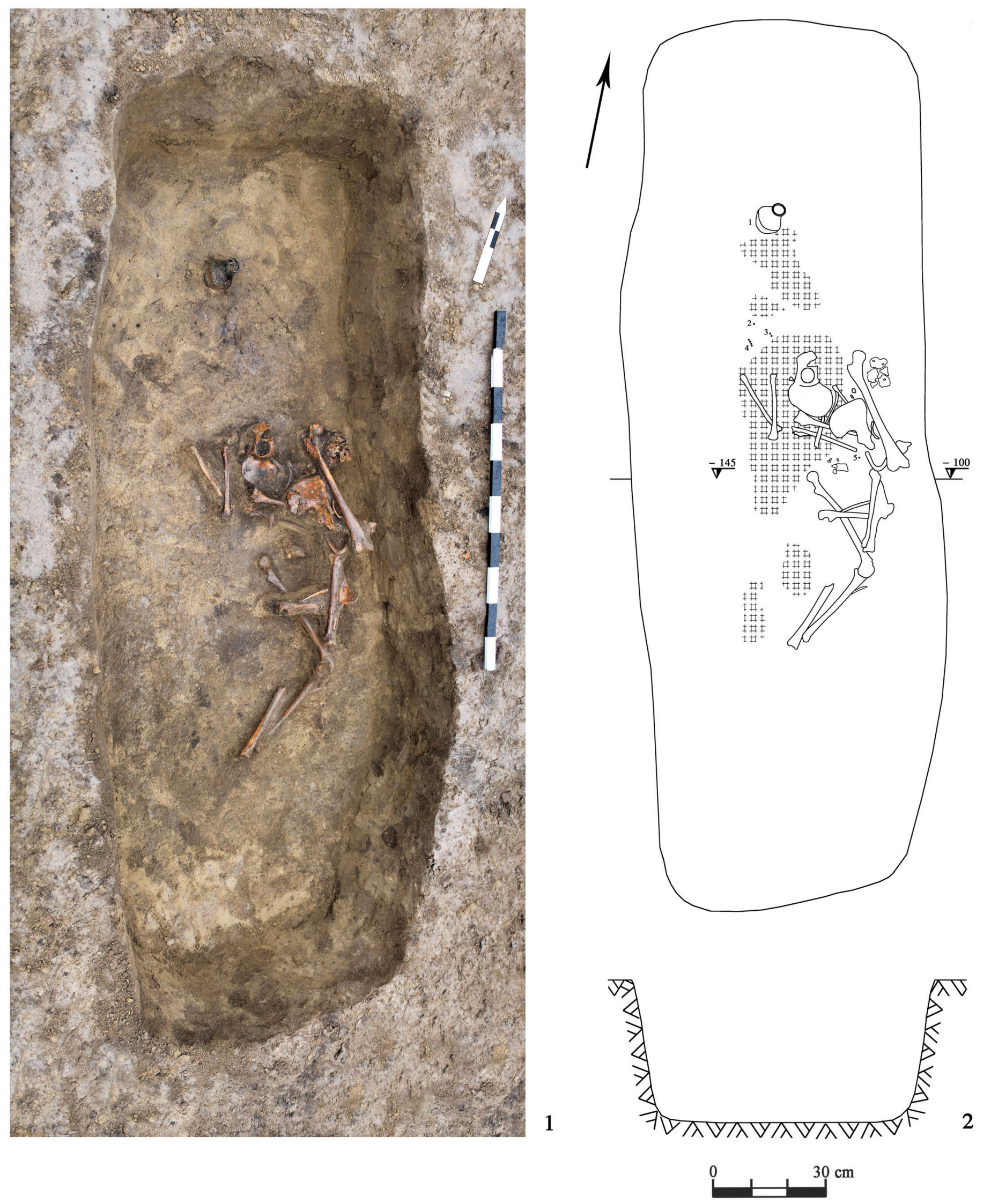

Fig. 8. Grave 2, plan and section. 

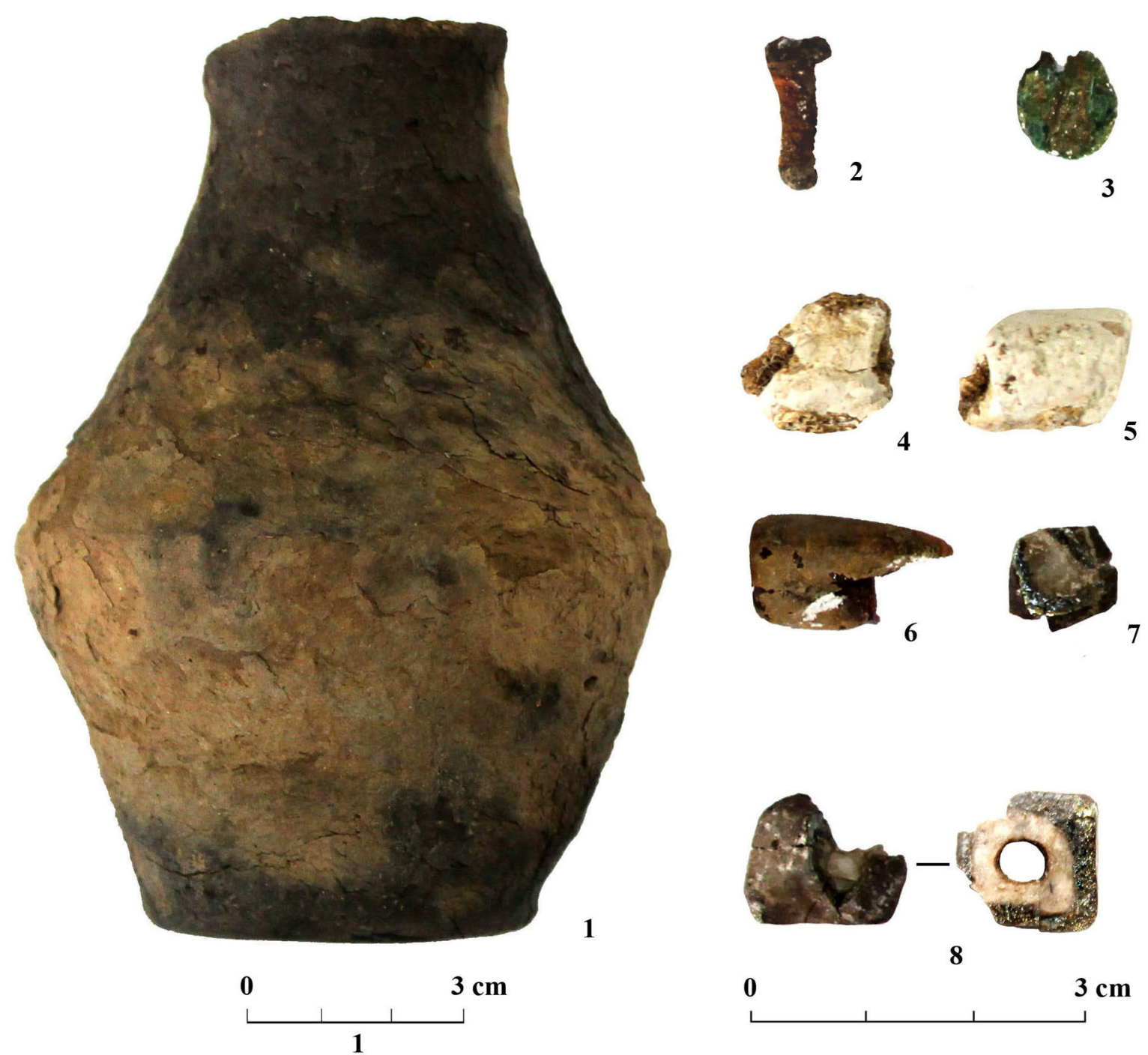

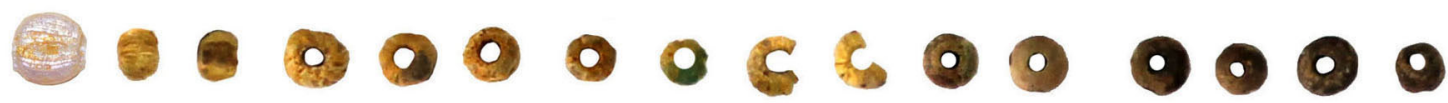
$\begin{array}{llllllllllllllll}9 & 10 & 11 & 12 & 13 & 14 & 15 & 16 & 17 & 18 & 19 & 20 & 21 & 22 & 23 & 24\end{array}$

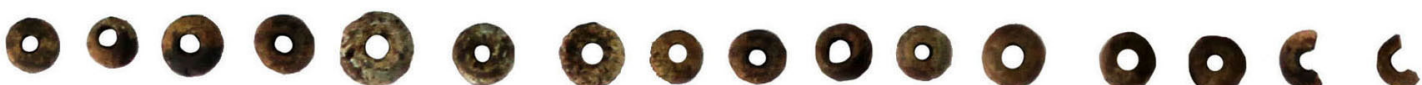
$\begin{array}{llllllllllllllll}25 & 26 & 27 & 28 & 29 & 30 & 31 & 32 & 33 & 34 & 35 & 36 & 37 & 38 & 39 & 40\end{array}$ 

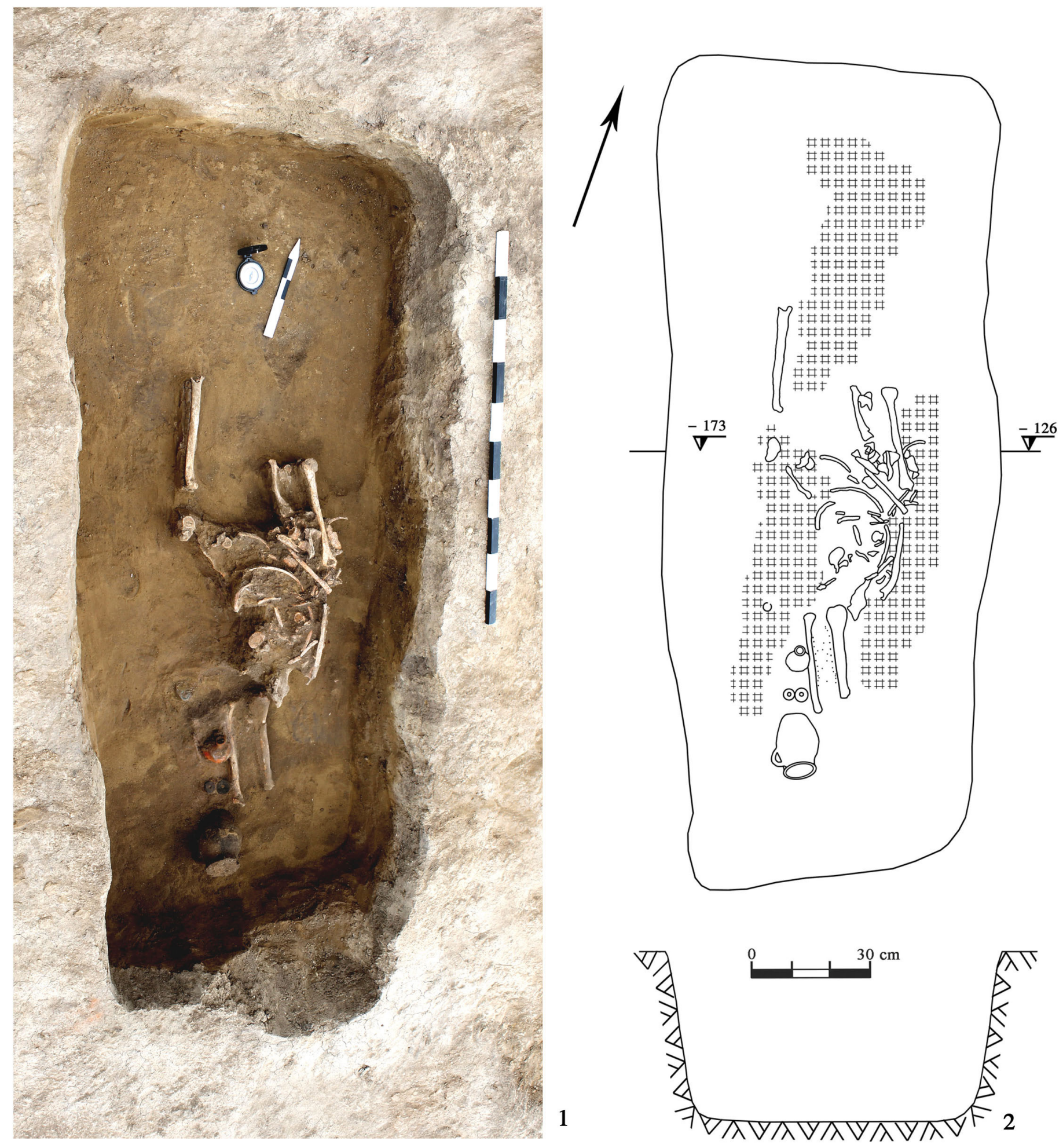

Fig. 10. Grave 3, plan and section. 

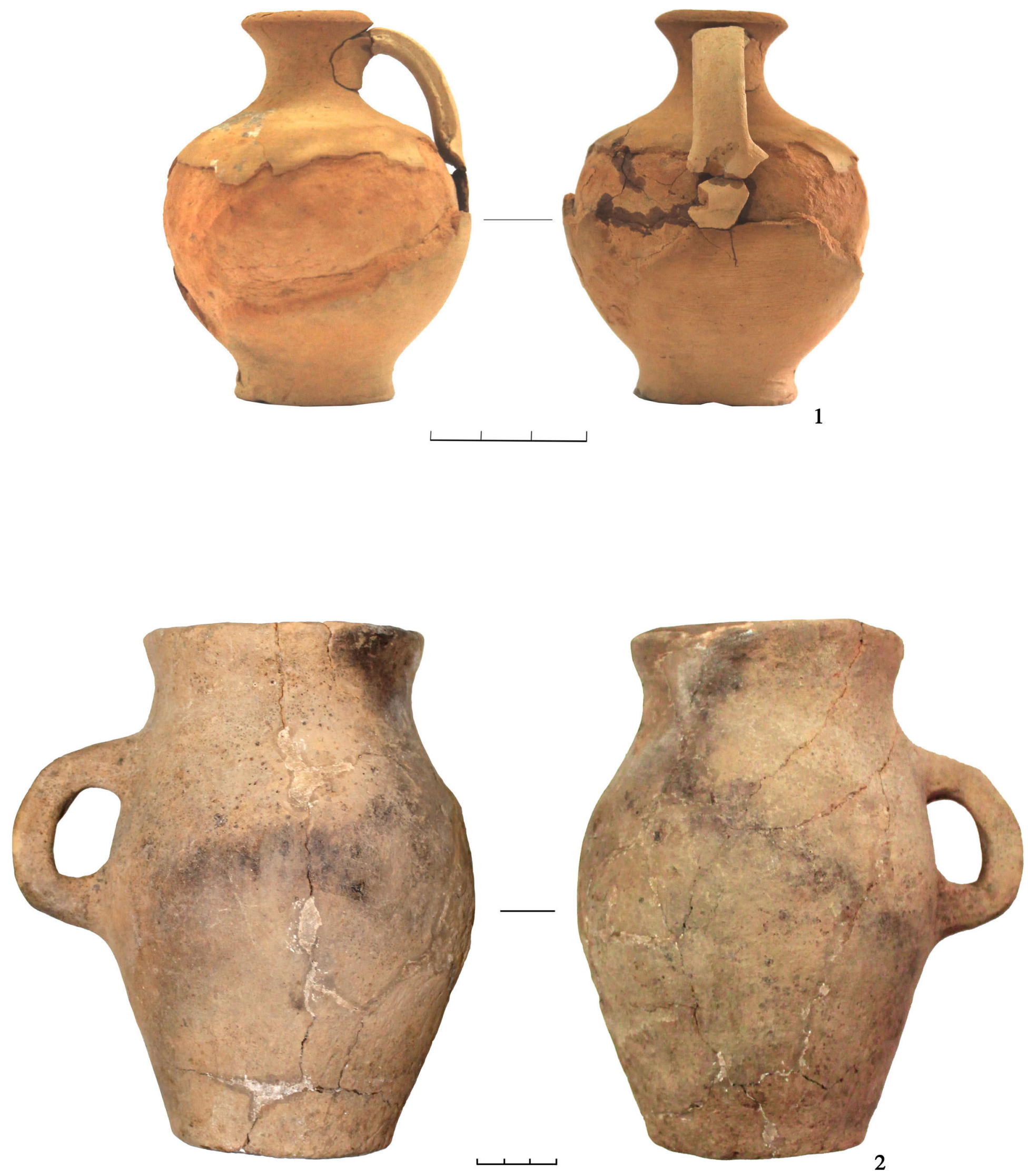

Fig. 11. Ceramic vessels found in the tomb 3. 

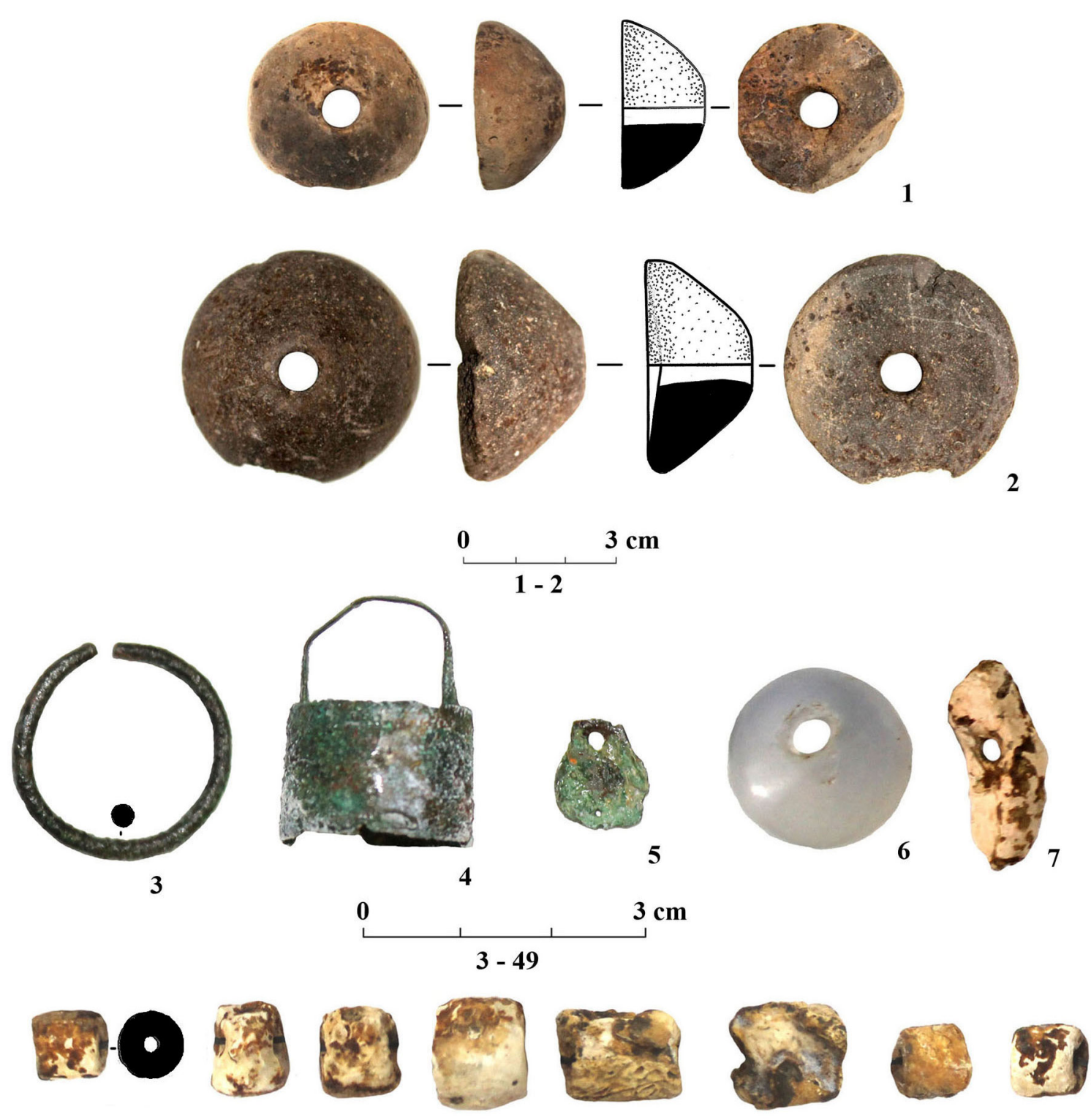

$8-15$

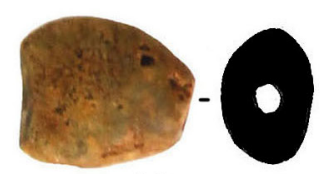

16

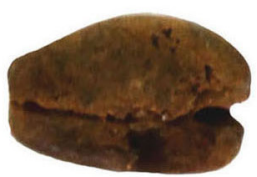

17

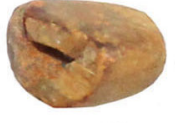

18

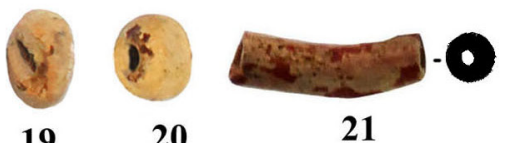

1920

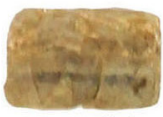

27

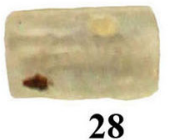

0600600006000600000 29 - 49 

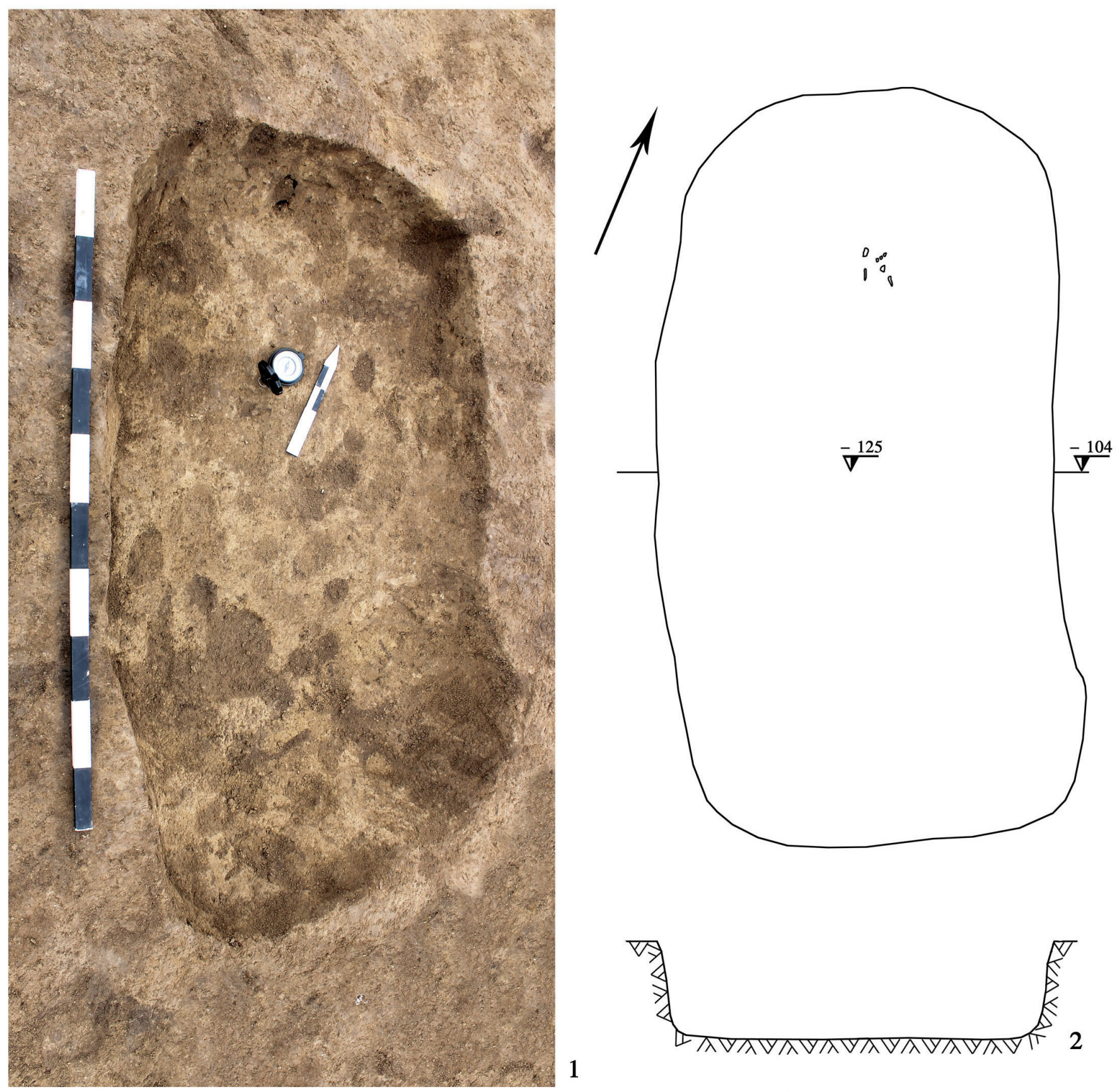

1
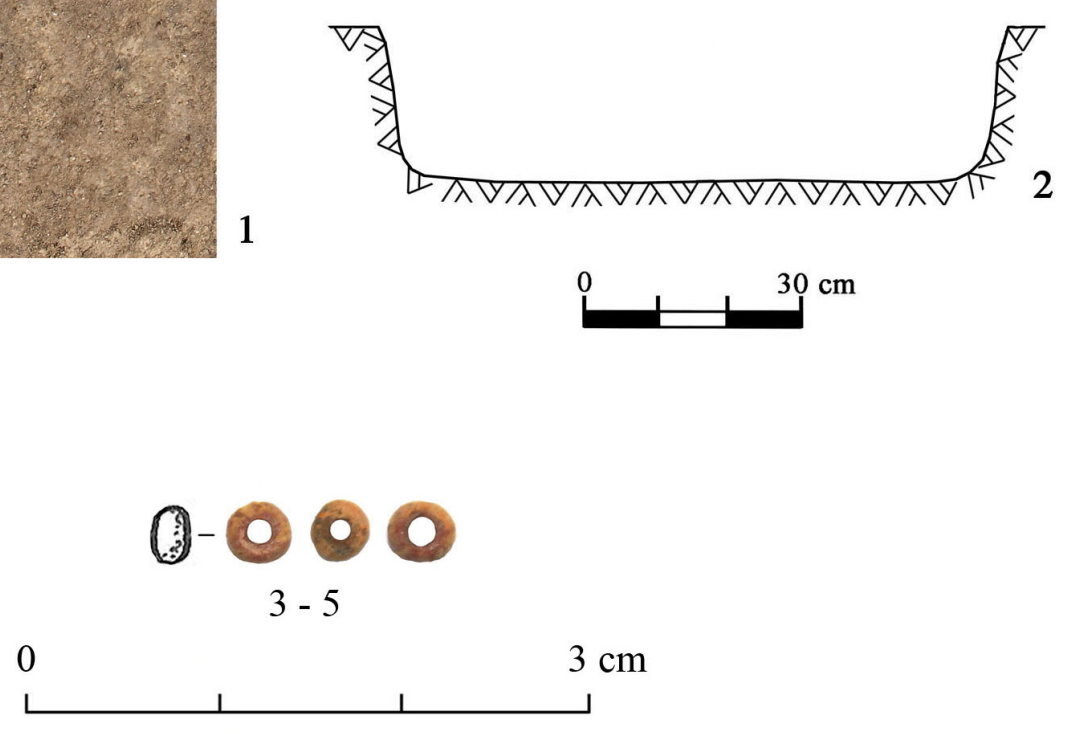

Fig. 13. Grave 4 (1-2) and glass beads (3) discovered in the tomb 4. 

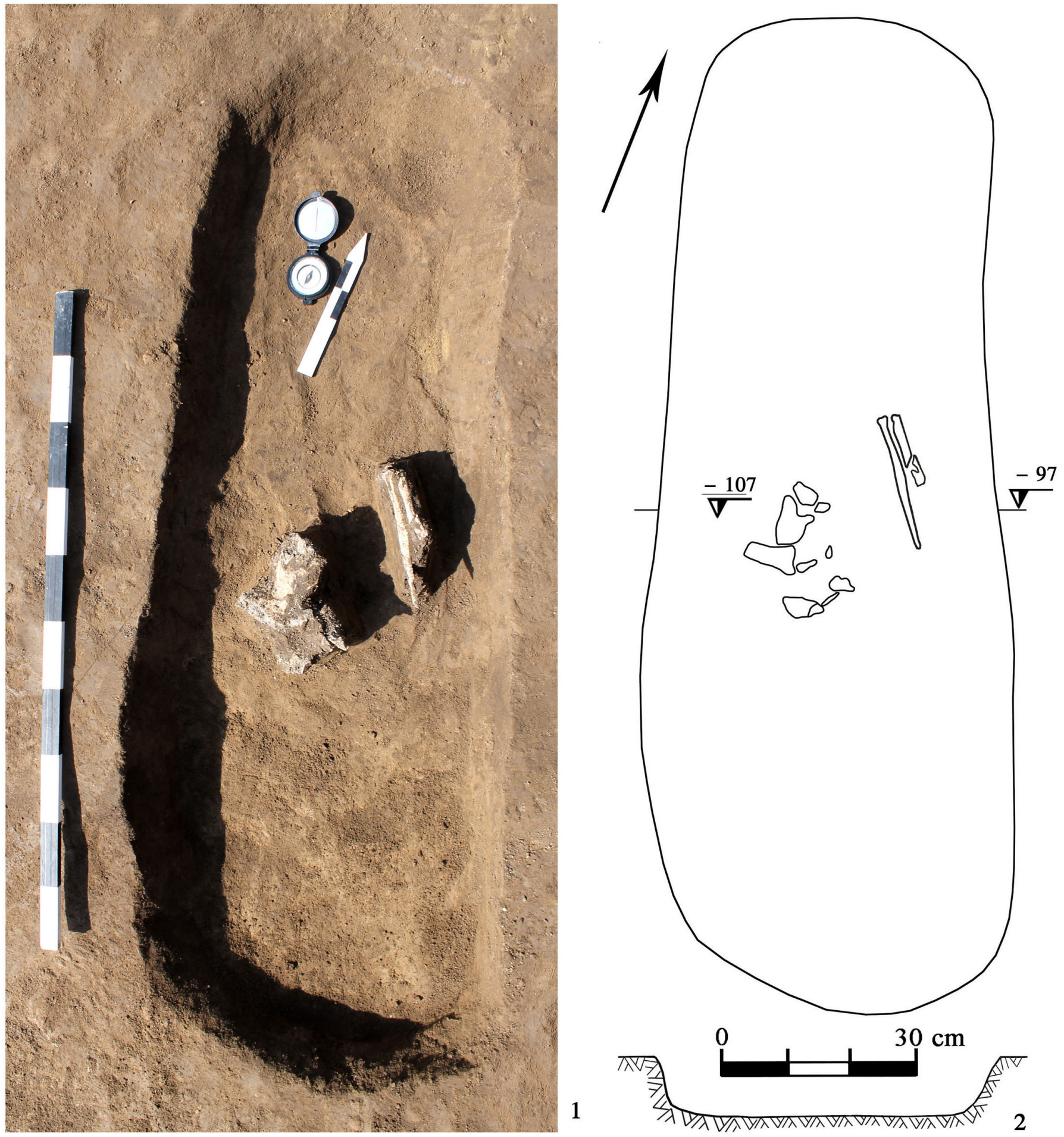

Fig. 14. Grave 5, plan and section. 

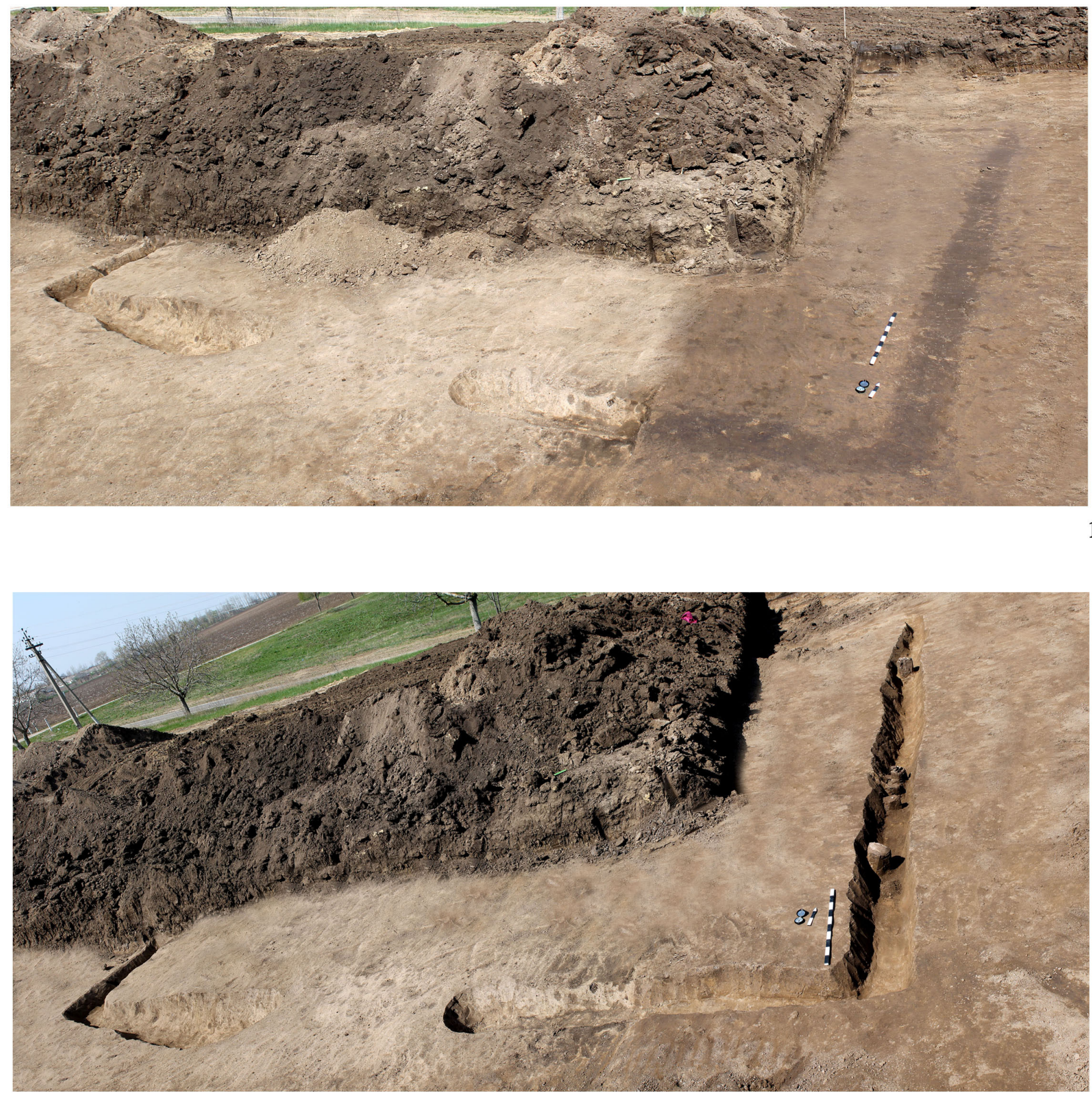
Studies
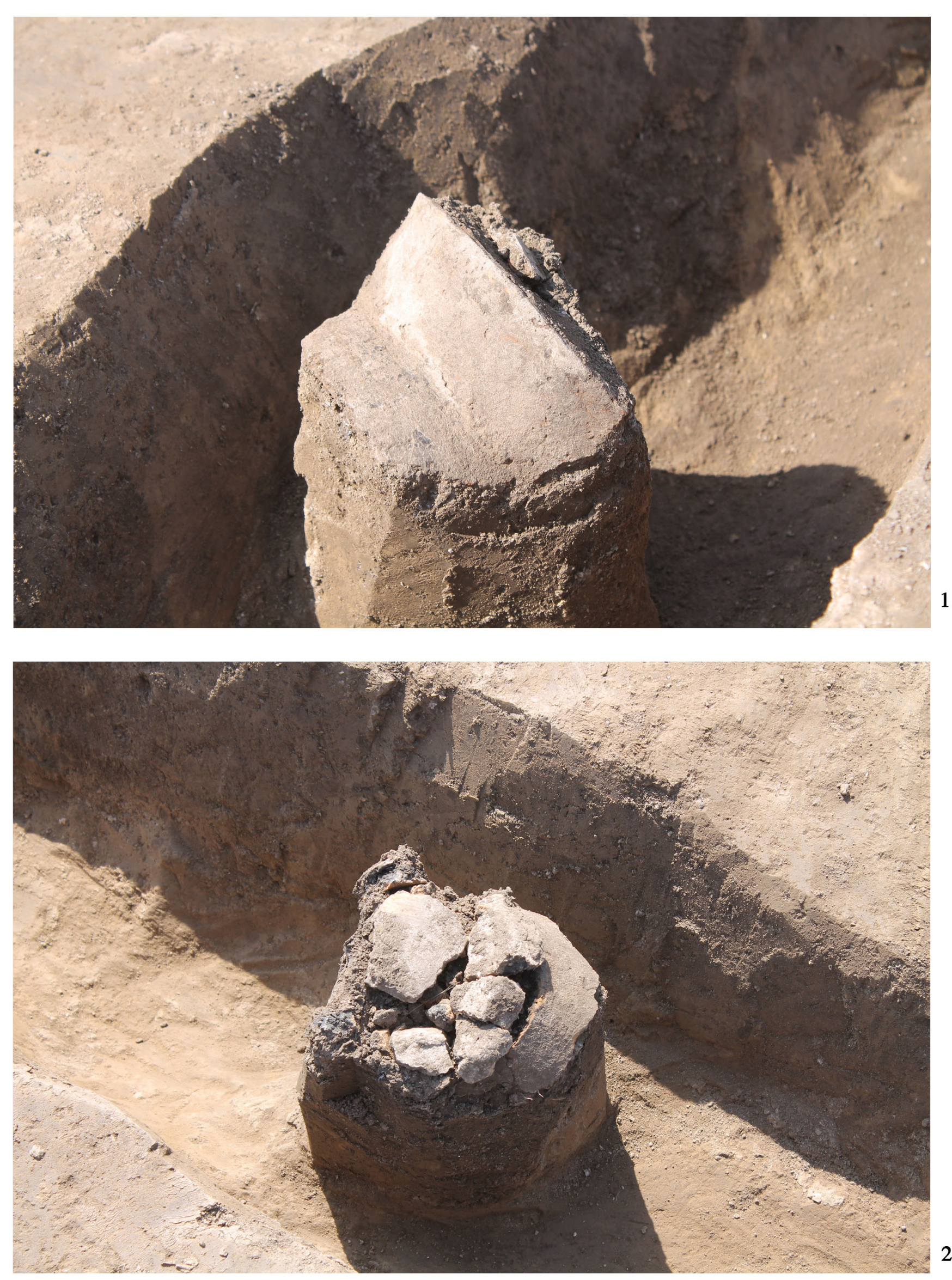

Fig. 16. Pottery fragments found in situ in the groove of the worship complex.

(46.3.3/2016

.

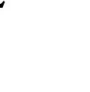



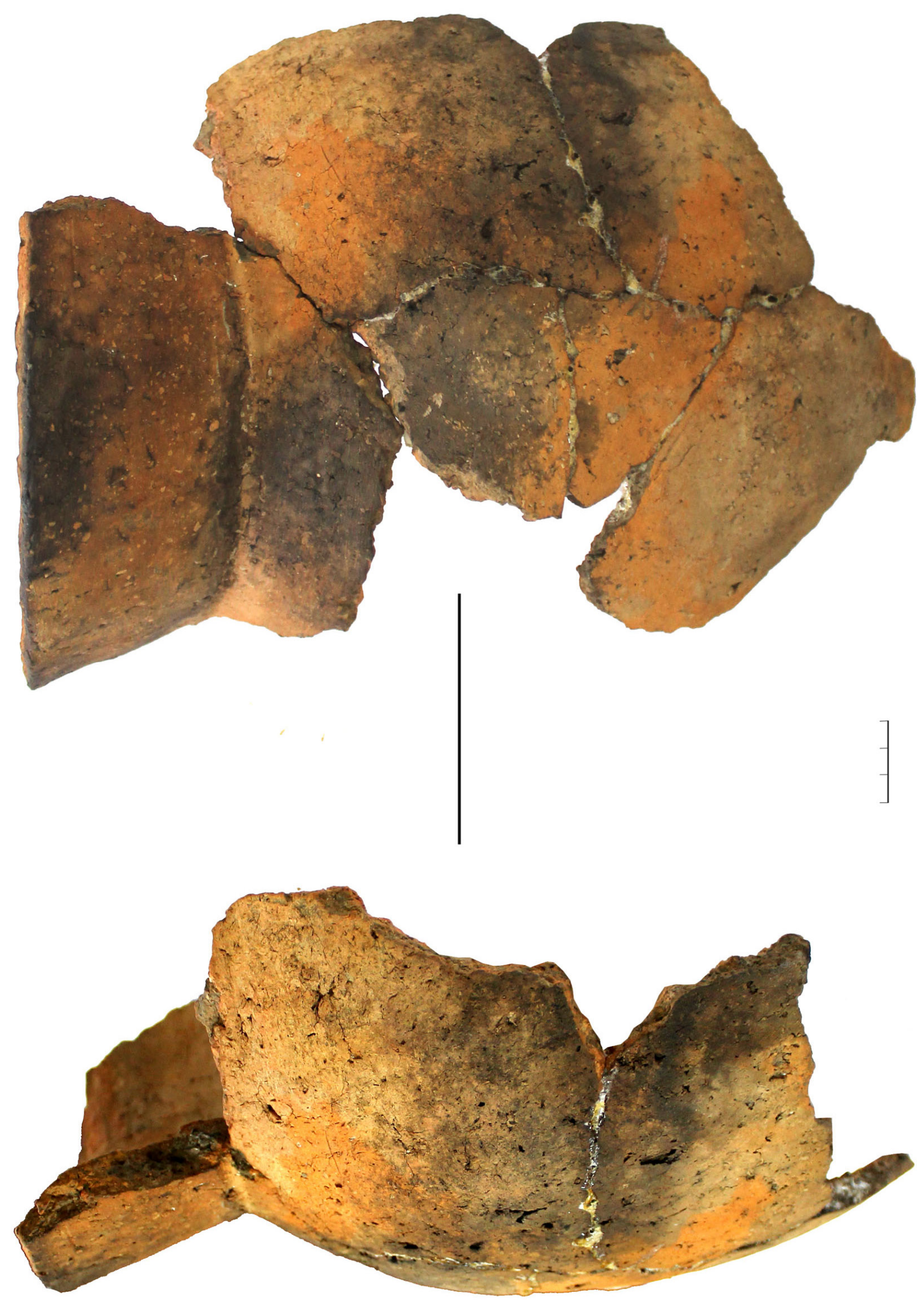

Fig. 17. Ceramic vessel found in the cult complex ditch. 

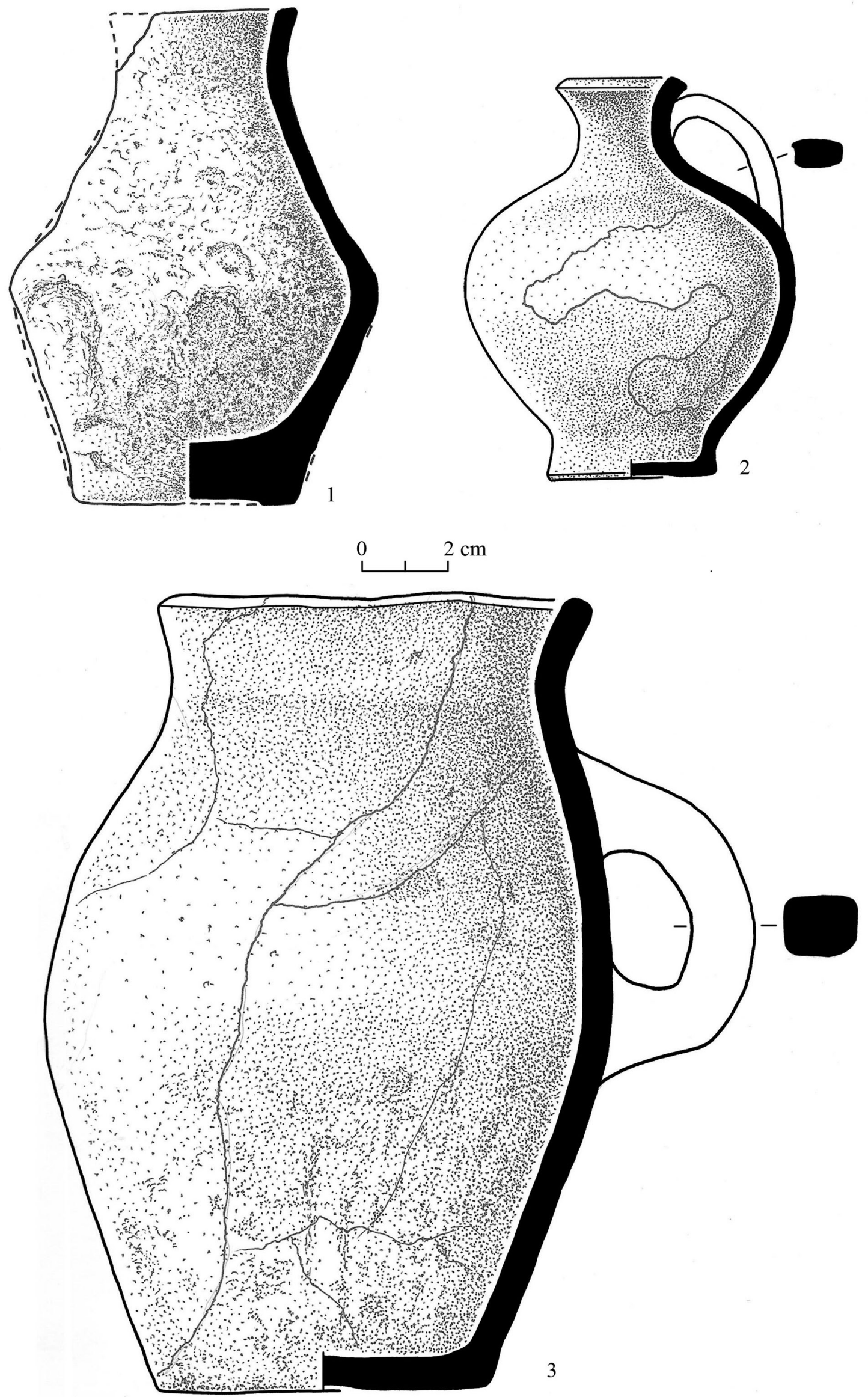

Fig. 18. Ceramic vessels found in graves $2(1)$ and $3(2,3)$. 